\title{
GCU
}

Glasgow Caledonian

University

University for the Common Good

\section{Oxidative stress responses and cellular energy allocation changes in microalgae following exposure to widely used human antibiotics}

Aderemi, Adeolu; Novais, Sara C.; Lemos, Marco F.L.; Alves, Luís M.; Hunter, Colin; Pahl, Ole

Published in:

Aquatic Toxicology

DOI:

10.1016/j.aquatox.2018.08.008

Publication date:

2018

Document Version

Author accepted manuscript

Link to publication in ResearchOnline

Citation for published version (Harvard):

Aderemi, A, Novais, SC, Lemos, MFL, Alves, LM, Hunter, C \& Pahl, O 2018, 'Oxidative stress responses and cellular energy allocation changes in microalgae following exposure to widely used human antibiotics', Aquatic Toxicology, vol. 203, pp. 130-139. https://doi.org/10.1016/j.aquatox.2018.08.008

\section{General rights}

Copyright and moral rights for the publications made accessible in the public portal are retained by the authors and/or other copyright owners and it is a condition of accessing publications that users recognise and abide by the legal requirements associated with these rights.

Take down policy

If you believe that this document breaches copyright please view our takedown policy at https://edshare.gcu.ac.uk/id/eprint/5179 for details

of how to contact us. 


\title{
Oxidative stress responses and cellular energy allocation changes in microalgae following exposure to widely used human antibiotics
}

\author{
Adeolu O. Aderemi ${ }^{1}$, Sara C. Novais ${ }^{2}$, Marco F. Lemos ${ }^{2}$, Luís M. Alves ${ }^{2}$, Colin Hunter ${ }^{1}$, \\ Ole Pahl ${ }^{1}$ \\ ${ }^{1}$ School of Engineering and Built Environment, Glasgow Caledonian University, United \\ Kingdom \\ ${ }^{2}$ MARE - Marine and Environmental Sciences Centre, ESTM, Instituto Politécnico de Leiria, \\ Portugal
}

\begin{abstract}
The individual effect of four human antibiotics on the microalgae Raphidocelis subcapitata was investigated following a 120-h exposure. The effects were assessed by analyzing growth, and biochemical parameters related with: 1) antioxidant capacity and oxidative damage by measuring superoxide dismutase (SOD) activity and lipid peroxidation (LPO) levels; and 2) cellular energy allocation (CEA) by quantifying the content in energy reserves, which represents the energy available $(E a)$, and the electron transport system activity that represents a measure of oxygen and cellular energy consumption $(E c)$. Growth yield inhibitory concentrations of sulfamethoxazole (18-30\%), clarithromycin (28.7\%), ciprofloxacin $(28 \%)$ and erythromycin (17-39\%) were found to elicit a considerable increase in Ec, thereby causing a significant decrease in the CEA. The elevated $E c$ can be a result of the need to respond to oxidative stress occurring under those conditions given the significant increase in SOD activity at these levels. For sulfamethoxazole, erythromycin and ciprofloxacin, the antioxidant responses do not seem to be enough to cope with the reactive oxygen species and prevent oxidative damage, given the elevated LPO levels observed. A stimulatory effect on growth yield was observed (up to $16 \%$ ) at ciprofloxacin lowest concentration, which highly correlated with the increase in CEA. Based on the no observed effect concentration (NOECs) and/or effective concentration $\left(\mathrm{EC}_{10}\right)$ results, $E c$, SOD and CEA were more sensitive than the classical endpoint of growth rate for all the tested antibiotics. By revealing the antibiotic stress effects in $R$. subcapitata at the cellular level, this study suggests CEA as a more reliable indicator of the organisms' physiological status.
\end{abstract}

Keywords: microalgal growth; antibiotics; toxicity; biomarkers; energy budget. 


\section{Introduction}

The wide use of antibiotics and their occurrence in the aquatic environment has been recognized as one of the emerging global environmental issues (Hernando et al., 2006). Antibiotics are bioactive molecules with an increasing use in both human and veterinary medicine for the prevention or treatment of microbial infections. It has been reported that the largest number of antibiotics used by humans in most countries consist of $\beta$-lactam antibiotics, including the sub-groups of penicillins and cephalosporins followed by sulfonamides, macrolides and fluoroquinolones (Kümmerer, 2009; ISD Scotland 2017). From the antibiotics administered to humans, a large portion (approximately 70\%) is excreted unmetabolized into municipal effluents and sewage treatment plants (STPs) as active compounds (Kummerer, 2009). The non-degradability of many antibiotics under aerobic conditions coupled with the inadequacy of STPs to remove them completely allows their entry into the aquatic environment via the sewage system (Halling-Sorensen et al., 1998). Although the recorded environmental levels are usually low, at $n g / \mathrm{L}$ to $\mathrm{ug} / \mathrm{L}$ in waters, they are "pseudopersistent" contaminants due to their continued release into the environment and permanent presence (Hernando et al., 2006).

The major concern of antibiotics, even at low concentrations, is associated with the development of resistance mechanisms by bacteria and its implications in human health (Gullberg et al., 2011). However, their bioactive nature coupled with continuous introduction into different environmental media have raised serious concerns about their toxicity to nontarget organisms (Orias and Perrodin, 2013; Johnson et al., 2015; Magdaleno et al., 2015). Microalgae as primary producers play a vital role in oxygen production in the aquatic ecosystems and occupy the lowest trophic level in food webs. Changes in their diversity and abundance could have an indirect but significant effect on the organisms at the higher trophic levels ( $\mathrm{Li}$ et al., 2006). It has been reported that among river organisms, blue-green algae (cyanobacteria) are the most sensitive $\left(\mathrm{EC}_{50}\right.$ less than $\left.0.1 \mathrm{mg} / \mathrm{L}\right)$ followed by the green algae $\left(\mathrm{EC}_{50}\right.$ between 0.3 and $>1200 \mathrm{mg} / \mathrm{L}$ ) to the toxic effects of antibiotics (Lai et al., 2009; Gonzalez-Pleiter et al., 2013). The green algae are eukaryotes and the cyanobacterial nature of their plastid genome and pathways makes their chloroplast susceptible as potential antibiotic target (McFadden and Roos 1999). Antibiotic toxicity to green algae could therefore be related to the inhibition and interference of the chloroplast metabolism such as photosynthetic procedures and interrelated protein synthesis, which disturb the function of photosynthetic apparatus and finally affect cell growth (Liu et al., 2011). 
This study examined four individual antibiotics (erythromycin (ERY), clarithromycin (CLA), ciprofloxacin (CPX), and sulfamethoxazole (SUF)) selected from a wide range of pharmaceuticals monitored in hospital wastewater in the European Union funded PILLS project (Helwig, 2013). Selection was based on hospital contribution, European wide usage and persistence in the environment (Helwig et al., 2013). These antibiotics are used in the treatment of a variety of bacterial infections and CPX inhibits bacterial DNA gyrase and prevent DNA replication, CLA and ERY inhibits protein synthesis by binding to the $23 \mathrm{~S}$ rRNA molecule of the bacterial ribosome while SUF inhibits bacterial folic acid synthesis (Van der Grinten et al., 2010; Gonzalez-Pleiter et al., 2013; Magdaleno et al., 2015). The studied antibiotics, due to their consumption, discharge, persistence and toxic properties, have been identified as antibiotics of high risk in the aquatic environment of Europe, USA, and Worldwide (Jones et al., 2002; Lienert et al., 2007; Besse and Garric, 2008; UBA, 2010; Hughes et al., 2013; Ortiz de Garcia et al., 2013).

The potential impact of a stressor in ecosystems requires the observation of effects at different levels of biological organization, starting at the molecular level and ending at the population or community level (Lemos et al, 2010; Connon et al., 2012). Many of the studies on the ecotoxic effects of pharmaceuticals are focused on the organismal or higher levels of biological organization and at such levels alone, the mechanisms of toxicity of the drugs are poorly understood and the predictive ability of measurements done is limited (Verslycke et al., 2004b). Over the last decades, biomarkers at suborganismal levels have been considered viable measures of responses to stressors (Huggett et al., 1992; Ferreira et al., 2015).

Changes in the antioxidant systems and modified macromolecules have served as biomarkers for a variety of xenobiotics (Gil and Pla, 2001). To prevent the damage induced by free radicals (products of cellular metabolism) to cells under oxidative stress, aerobic organisms have developed antioxidant enzyme defences such as superoxide dismutase (SOD). SOD is involved in the reduction of superoxide radical into hydrogen peroxide $\left(\mathrm{H}_{2} \mathrm{O}_{2}\right)$ (Van Camp et al., 1994), which readily become broken down by CAT into water and oxygen (De Zwart et al., 1999). Failure of these defences to detoxify excess reactive oxygen species (ROS) can lead to significant oxidative damage including lipid peroxidation (LPO) (Soto et al., 2011).

Other types of biomarkers that have been used successfully are those linked to metabolism and energetics (Verslycke et al., 2004a). According to De Coen et al. (1995), the allocation of specific amounts of energy to basal metabolism, growth, and reproduction in an organism 
will differ in response to changing environmental conditions and exposure to a pollutant could cause a disturbance in the allocation. Based on this concept, single integrated bioassay such as the cellular energy allocation (CEA) assay was developed as a biomarker tool to evaluate the effects of toxic stress on the metabolic balance or net energy budget of organisms (De Coen et al., 1995; Verslycke et al. 2004a). The difference between available energy reserves (based on the biochemical analysis of total carbohydrate, total lipid, and total protein content) and energy consumption (estimated by measuring the electron transport system activity (ETS) at the mitochondrial level) has been shown to be indicative of an organism's overall condition (De Coen and Janssen 2003a).

The aim of this study was to link the selected antibiotic effects in green algae at the cellular level to an outcome at the organismal level of organization, for example growth inhibition, elucidating mechanisms of toxicity for these compounds. This study was therefore carried out to investigate the effects of SUF, ERY, CLA, and CPX by assessing antibiotic effects on (1) growth yield and growth rate of the green microalgae, $R$. subcapitata; and (2) biochemical parameters associated with antioxidant capacity (SOD), oxidative damage (LPO) and cellular energy allocation (CEA). 


\section{Materials and Methods}

\subsection{Microalgal culture and growth inhibition test}

Axenic unicellular cultures of $R$. subcapitata (CCAP 278/4) purchased from Culture Collection of Algae and Protozoa (CCAP) were cultivated in $500 \mathrm{~mL}$ conical flasks containing sterile Jaworski's Medium (JM). Cultures were maintained at $120 \mathrm{rpm}$ on an orbital shaker in an environmental chamber at $20 \pm 1^{\circ} \mathrm{C}$ under continuous illumination in the range $40-50 \mu \mathrm{mol} \mathrm{m} \mathrm{m}^{-2} \mathrm{~s}^{-1}$ of photosynthetic active radiation. To keep the cultures in an exponential growth phase, algae were aseptically transferred to fresh media every 3-4 days.

Stock solutions of the test antibiotics, SUF (CAS no. 723-46-6); ERY hydrate (CAS no. 11407-8); CLA (CAS no. 81103-11-9) and CPX (CAS no. 85721-33-1) purchased from Sigma with $\geq 95 \%$ purity were prepared directly in JM fresh algal medium, immediately before each toxicity test. Sublethal concentrations of each antibiotic were individually tested against $R$. subcapitata: $0,0.24,1.97,3.95$ and $13.83 \mu \mathrm{M}$ of SUF; $0,8 \times 10^{-3}, 1.19 \times 10^{-2}, 1.7 \times 10^{-2}$ and $4.08 \times 10^{-2} \mu \mathrm{M}$ of ERY; $0,1.3 \times 10^{-3}, 3.3 \times 10^{-3}, 4.6 \times 10^{-3}$ and $7.3 \times 10^{-3} \mu \mathrm{M}$ CLA; and 0 , $3.02,6.04,12.08$, and $24.17 \mu \mathrm{M}$ of $\mathrm{CPX}$. Methanol and hydrochloric acid $(\mathrm{HCl})$ were used as solvents for CLA and CPX respectively. Solvent controls were used in CPX and CLA assays. In the case of CLA, the final concentration of methanol in the assay media was $\leq 0.0005 \%$ $(\mathrm{v} / \mathrm{v})$ while the final concentration of $\mathrm{HCl}$ in the assay media in $\mathrm{CPX}$ exposure was $\leq$ $0.00146 \%(\mathrm{v} / \mathrm{v})$. Although not shown, both concentrations did not result in any significant effects on the growth of the test organism. The $\mathrm{pH}$ of the test media was monitored before and after the tests.

To generate enough intracellular materials for biomarker studies, the bioassays were carried out in $100 \mathrm{~mL}$ Erlenmeyer flasks each containing $45 \mathrm{~mL}$ of test solution. Tests were performed in accordance with OECD Test Guideline 201 (OECD, 2006) with minor modifications. In each flask, a specified volume of the culture of $R$. subcapitata in exponential growth phase was diluted with a known volume of JM (with or without pharmaceuticals), to obtain equal amounts of initial cell biomass in the range $1.5 \times 10^{5}$ to 3.0 $\mathrm{x} 10^{5}$ cells $/ \mathrm{mL}$ in both the treatments and the control groups. Each concentration of the pharmaceutical and the control was tested using seven replicates $(n=7)$. The tests were run for $120 \mathrm{~h}$ under the same standard conditions used for the inoculum culture. The positions of test flasks were randomized and changed every $24 \mathrm{~h}$ for uniform distribution of light (USEPA, 2002). Cell growth was determined every $24 \mathrm{~h}$ using an automatic cell counter (Micro 
Counter $^{\circledR} 1100$, Celeromics) in bright field configuration. The $\mathrm{pH}$ of the test media in each treatment and the control groups were measured at the commencement and at the end of the experiment and were between 7.35 to 7.82 . To determine the stability of the pharmaceuticals in the test systems, samples were taken at the 0,48 , and $120 \mathrm{~h}$ and then stored at $-20^{\circ} \mathrm{C}$ until further analysis.

\subsection{Biochemical biomarkers determination}

\subsubsection{Cell harvesting, disruption, and enzyme extraction}

At the end of exposure period, algal cultures were harvested in $50 \mathrm{~mL}$ sterile tubes following centrifugation at $5000 \mathrm{~g}$ for $10 \mathrm{~min}$. The resultant pellet was then resuspended in $300 \mu \mathrm{L}$ of $50 \mathrm{mM}$ sodium phosphate buffer $(\mathrm{pH} \mathrm{7})$ containing $1 \mathrm{mM}$ phenylmethylsulfonyl fluoride (PMSF). For homogenization, suspension was transferred to tubes containing $300 \mu \mathrm{L}$ of $0.42-$ $0.6 \mathrm{~mm}$ glass beads (Sigma) and algal cells were disrupted for $15 \mathrm{~min}$ at $6.5 \mathrm{~ms}^{-1}$ in a bead beater (FastPrep ${ }^{\circledR}-24$, MP Biomedicals). Enzymes from the disrupted cells were extracted in $1 \mathrm{~mL}$ of sodium phosphate buffer (with PMSF) and the tubes centrifuged at $10000 \mathrm{~g}$ for 20 min at $4^{\circ} \mathrm{C}$. The supernatant was stored at $-80^{\circ} \mathrm{C}$ for biomarker measurements. Seven replicates per treatment were used for each biomarker determination. All biomarkers were assayed, in triplicates, using a microplate reader (Synergy H1 Hybrid, BioTek).

\subsubsection{Analysis of oxidative stress biomarkers}

Superoxide dismutase (SOD) activity was assayed by monitoring the inhibition of the enzymatic reduction of cytochrome $\mathrm{c}$ by xanthine oxidase using xanthine/xanthine oxidase as source of superoxide radicals based on the protocol of McCord and Fridovich (1969) and the unit of activity expressed as U/10 ${ }^{6}$ cells ( $\mathrm{Li}$ et al., 2006). Lipid peroxidation (LPO) content in the algal samples was determined by measuring the concentration of malondialdehyde (MDA) using the thiobarbituric acid reactive substances (TBARs) assay (Ohkawa, 1979; Bird and Draper, 1984). The extinction coefficient of $1.56 \times 10^{5} \mathrm{M}^{-1} \mathrm{~cm}^{-1}$ was used for thiobarbituric acid (TBA) and LPO expressed as nmol TBARs $/ 10^{6}$ cells.

\subsubsection{Energy available (Ea - Protein, carbohydrate, and lipid fractions)}

Total protein content in the samples was determined using Bradford's method (Bradford, 1976). The absorbance was measured at $600 \mathrm{~nm}$ using bovine $\gamma$-globulin as standard. Total lipids were extracted following the method of Bligh and Dyer (1959) with minor modifications. To $150 \mu \mathrm{L}$ of sample, $250 \mu \mathrm{L}$ of chloroform (spectrophotometric grade, 
Sigma), $250 \mu \mathrm{L}$ of methanol (spectrophotometric grade, Sigma) and $125 \mu \mathrm{L}$ Milli-Q water were added. After centrifugation at $1000 \mathrm{~g}$ for $5 \mathrm{~min}$, the top phase and interphase were removed and $500 \mu \mathrm{L}$ of $\mathrm{H}_{2} \mathrm{SO}_{4}$ was added to $100 \mu \mathrm{L}$ of lipid extract and charred for $15 \mathrm{~min}$ at $200^{\circ} \mathrm{C}$. After cooling down to $20^{\circ} \mathrm{C}, 1.5 \mathrm{~mL}$ of deionised water was added, and total lipid content was determined by measuring the absorbance at $375 \mathrm{~nm}$ using tripalmithin as standard.

To determine the total carbohydrate content (De Coen and Janssen, 1997), $50 \mu \mathrm{L}$ of 15\% trichloroacetic acid was added to the $150 \mu \mathrm{L}$ of the samples and held at $-20^{\circ} \mathrm{C}$ for $10 \mathrm{~min}$. After centrifugation at $1000 \mathrm{~g}$ for $10 \mathrm{~min}$, total carbohydrate content of the supernatant fraction was quantified by adding $50 \mu \mathrm{L}$ of $5 \%(\mathrm{v} / \mathrm{v})$ phenol and $200 \mu \mathrm{L}$ of $18 \mathrm{M} \mathrm{H}_{2} \mathrm{SO}_{4}$ to 50 $\mu \mathrm{L}$ extract. After $30 \mathrm{~min}$ of incubation at $20^{\circ} \mathrm{C}$, the absorbance was measured at $492 \mathrm{~nm}$ with glucose as standard.

The different energy reserve fractions were then transformed into energetic equivalents by using their respective energy of combustion $\left(17,500 \mathrm{~mJ} \mathrm{mg} \mathrm{glycoge{ } ^ { - 1 }}\right.$, 24,000 mJ mg protein $^{-1}$, and 39,500 mJ mg lipid ${ }^{-1}$ ) (Gnaiger, 1983), and summed to calculate total Ea.

\subsubsection{Energy consumption (Ec)}

Mitochondrial Electron Transport System (ETS) activity is directly linked to cellular oxygen consumption and metabolism, and as a result, the measurement of this system has been suggested as a valid alternative to whole organism respiration rates (King and Packard, 1975). ETS was measured according to King and Packard (1975) with major modifications as described below. To $30 \mu \mathrm{L}$ of sample or blank, $20 \mu \mathrm{L}$ of homogenizing buffer $(0.3 \mathrm{M}$ Tris, 15\% (w/v) polyvinyl pyrrolidone (PVP), $459 \mu \mathrm{M}$ MgSO4, $1.5 \mathrm{ml}$ Triton X-100, $\mathrm{pH} 8.5$ ), and $100 \mu \mathrm{L}$ of buffered substrate solution (reduced nicotinamide adenine dinucleotide (NADH) $(1.79 \mathrm{mM})$ and reduced nicotinamide adenine dinucleotide phosphate (NADPH) $(280 \mu \mathrm{M})$ in $0.13 \mathrm{M}$ Tris, $0.3 \%(\mathrm{w} / \mathrm{v})$ Triton $\mathrm{X}-100, \mathrm{pH} 8.5)$ were added. The reaction was started by adding $50 \mu \mathrm{L}$ of $8 \mathrm{mM}$ p-iodonitrotetrazolium (INT) and the change in absorbance measured at $490 \mathrm{~nm}$ over a $3 \mathrm{~min}$ period at $20^{\circ} \mathrm{C}$. The amount of formazan formed was calculated by using extinction coefficient, $\varepsilon=15900 /$ M.cm (De Coen and Janssen, 1997).

The cellular respiration rate $(E c)$ was determined by using the ETS data, based on the theoretical stoichiometrical relationship that for each $2 \mu \mathrm{mol}$ of INT-formazan formed, 1 $\mu \mathrm{mol}$ of $\mathrm{O}_{2}$ was consumed in the electron transport system. The calculated quantity of oxygen 
consumed was transformed into energetic equivalents by using the specific oxyenthalpic equivalents for an average lipid, protein, and carbohydrate mixture of $480 \mathrm{~kJ} \mathrm{~mol} \mathrm{O}{ }^{-1}$ (Gnaiger, 1983).

\subsubsection{Cellular energy allocation (CEA)}

The CEA values, standardised to $10^{6}$ cells, were calculated based on seven replicate measurements of lipid, carbohydrate and protein content and ETS activity for each control and treatment as follows (Verslycke et al., 2004a):

$\mathrm{CEA}=E a / E c$

Where:

$E a($ available energy $)=$ carbohydrate + lipid + protein $\left(\mathrm{mJ} / 10^{6}\right.$ cells $)$

$E c($ energy consumption $)=$ ETS activity $\left(\mathrm{mJ} / 10^{6}\right.$ cells $\left./ \mathrm{h}\right)$

As in Verslycke et al. (2004a), it can be deduced from this calculation that a decline in CEA indicates a reduction in available energy and/or a higher energy expenditure, resulting in a lower amount of energy available for growth.

\subsection{Determination of antibiotic concentration}

Measurement of the antibiotics was preformed using liquid chromatography mass spectrometry (LC-MS/MS). Samples from algae were filtered through $0.2 \mu \mathrm{m}$ cellulose filter prior to use for LC-MS/MS analysis. A thermo Scientific Q-exactive Orbitrap mass spectrometer was used, fitted with a Dionex Ultimate 3000 RS Pump, Dionex Ultimate 3000 RS Autosampler (Temperature controlled at $10^{\circ} \mathrm{C}$ ) and Dionex Ultimate 3000 RS Column Compartment (Temperature controlled at $30^{\circ} \mathrm{C}$ ); and operated in the positive ion mode. The LC column was a Thermo Scientific Accucore C18 chromatography column with particle size of 2.6 microns and dimensions $100 \times 2.1 \mathrm{~mm}$ employed at a constant flow rate of 0.2 $\mathrm{mL} / \mathrm{min}$. For each sample, $10 \mu \mathrm{L}$ was injected using an auto-sampler. Mobile phase consisted of acetonitrile (Optima ${ }^{\circledR}$, LCMS grade, ex Fisher) and $10 \mathrm{mM}$ ammonium formate (adjusted to $\mathrm{pH} 3.5$ by formic acid) for ERY, SUF and CLA; and methanol and $0.1 \%$ formic acid in water for CIP. Deionised water was provided at $18 \mathrm{M} \Omega$ purity by an Elga "Purelab Classic" water deioniser. All detections were performed by mass spectrometry (MS), in which the MS 
transition (precursor ion $\rightarrow$ product ion) was $734.47 \rightarrow 158.1$ for ERY, $748.48 \rightarrow 158.1$ for CLA, $254 \rightarrow 156$ for SUF, and $332 \rightarrow 288$ for CPX.

\subsection{Statistical analysis}

Percent growth inhibition was calculated for the response variables: growth yield and growth rate. Statistical differences in the biomarker responses in the treatments compared to the controls were analyzed after normality test (Shapiro-Wilk) by one-way ANOVA (SPSS ${ }^{\circledR}$ v22 software) taking $p<0.05$ as significant, according to Tukey's and Games-Howell post hoc tests. A correlation matrix was also set up and Pearson correlation coefficients calculated for the measured parameters using SPSS v22 statistics software. $\mathrm{EC}_{10}$ values were calculated for growth parameters and CEA using regression analysis.

\section{Results}

\subsection{Stability of the antibiotics}

Initial concentrations and stability of antibiotics under bioassay conditions were examined based on the OECD (2000) guideline. Analyses were performed in the assay media in the absence of microalgal cells at $0 \mathrm{~h}$ and in the presence of $R$. subcapitata at $48 \mathrm{~h}$ and $120 \mathrm{~h}$ of exposure. The results are presented in Table S1 (supplementary material).

For ERY, the measured exposure concentrations were within $80-120 \%(\mathrm{OECD}, 2006)$ of the nominal and, thus the nominal concentrations were used for data analyses throughout the study. For CPX, the average measured concentrations were within $93-116 \%$ of the three highest nominal concentrations at $48 \mathrm{~h}$ but dropped to $44-78 \%$ of the nominals by $120 \mathrm{~h}$. The average measured concentrations of SUF decreased in the three highest treatment groups and the measured concentrations were within $54-102 \%$ and $26-46 \%$ of their nominals after $48 \mathrm{~h}$ and $120 \mathrm{~h}$ respectively. There was an apparent substantial degradation of CLA with the initial measured concentrations decreasing from $89-105 \%$ of the nominal values at $0 \mathrm{~h}$ to $7.2-14.6 \%$ and $2.6-9.3 \%$ of the nominals at $48 \mathrm{~h}$ and $120 \mathrm{~h}$ respectively. 
The effect concentrations were calculated and expressed as geometric mean exposure concentrations instead of the nominals for CPX, SUF (except for the lowest concentration) and CLA in accordance with OECD guideline (OECD, 2000).

\subsection{Effects of antibiotics on algal growth}

In ERY exposure, algal growth yield was not significantly inhibited until the $72 \mathrm{~h}$ after treatment at the two highest concentrations while a significant decrease $(p<0.05)$ in the growth yield of $R$. subcapitata was noticed at the highest concentrations of CLA and CPX from the $96 \mathrm{~h}$ following exposure (data not shown). SUF had no effect on algal growth until the $48 \mathrm{~h}$ when inhibition was observed at the highest concentration. Table 1 shows a concentration-dependent percentage inhibition of algal growth yield and growth rate by the antibiotics after $120 \mathrm{~h}$ of exposure. It can be observed that the maximum percentage inhibition of growth yield was $30.3,39.2,28.7$, and $28.2 \%$ and that of growth rate was 11.9, 13.1, 9.8, and $10.6 \%$ at the highest concentrations of SUF, ERY, CLA, and CPX, respectively. Stimulatory responses or hormetic effects were induced by the lower exposure concentrations of SUF, ERY, and CPX following $120 \mathrm{~h}$. The toxicity rankings of the pharmaceuticals to growth in $R$. subcapitata after $120 \mathrm{~h}$ is as follows: CLA $>$ ERY $>$ SUF $>$ CPX.

Table 1. Percent inhibition of algal growth yield and growth rate by the tested antibiotics after $120 \mathrm{~h}$ of exposure

\begin{tabular}{llll}
\hline Drug & $\begin{array}{l}\text { Concentration } \\
(\mu \mathrm{M})\end{array}$ & $\begin{array}{l}\text { \% Inhibition of growth yield } \\
\text { Mean } \pm \mathrm{SE}\end{array}$ & $\begin{array}{l}\text { \% Inhibition of growth rate } \\
\text { Mean } \pm \mathrm{SE}\end{array}$ \\
\hline Sulfamethoxazole & 0.24 & $(-) 36.4^{* * *} \pm 4.39$ & $(-) 10.3^{* * *} \pm 1.13$ \\
& 1.58 & $18.6^{* *} \pm 3.18$ & $6.8^{* * *} \pm 1.27$ \\
& 2.96 & $28.9^{* * *} \pm 1.22$ & $11.2^{* * *} \pm 0.55$ \\
& 8.30 & $30.3^{* * *} \pm 2.23$ & $11.9^{* * *} \pm 1.03$ \\
\hline Erythromycin & $8.00 \times 10^{-3}$ & $(-) 11.8 \pm 3.27$ & $(-) 2.9 \pm 0.76$ \\
& $1.19 \times 10^{-2}$ & $4.6 \pm 3.79$ & $1.2 \pm 1.08$ \\
& $1.70 \times 10^{-2}$ & $16.9^{*} \pm 4.10$ & $4.9^{*} \pm 1.30$ \\
& $4.08 \times 10^{-2}$ & $39.2^{* * *} \pm 3.39$ & $13.1 * * * \pm 1.39$ \\
\hline Clarithromycin & $2.8 \times 10^{-4}$ & $1.8 \pm 4.76$ & $0.45 \pm 1.47$ \\
& $4.6 \times 10^{-4}$ & $1.4 \pm 4.74$ & $0.31 \pm 1.41$
\end{tabular}




\begin{tabular}{llll} 
& $6.0 \times 10^{-4}$ & $6.2 \pm 7.62$ & $2.1 \pm 2.46$ \\
& $7.6 \times 10^{-4}$ & $28.7^{* *} \pm 2.73$ & $9.8^{* *} \pm 1.16$ \\
\hline Ciprofloxacin & 3.7 & $(-) 16.0 \pm 10.59$ & $(-) 4.1 \pm 2.71$ \\
& 5.8 & $(-) 4.0 \pm 3.95$ & $(-) 1.1 \pm 1.23$ \\
& 11.5 & $7.2 \pm 3.28$ & $2.4 \pm 1.41$ \\
& 19.1 & $28.2^{* *} \pm 4.03$ & $10.6^{* *} \pm 1.61$ \\
\hline
\end{tabular}

$\mathrm{SE}$, standard error of 6 to 7 replicates; negative values $=$ hormesis or stimulatory response. $* p<0.05, * * p<$ $0.01, * * * p<0.001$.

\subsection{Effects of antibiotics on superoxide dismutase (SOD) activity}

The effects of the individual antibiotics on the SOD activity of $R$. subcapitata after $120 \mathrm{~h}$ of exposure are shown in Figure 1a-d. A concentration-dependent significant increase in the SOD activity of the microalgae $(F=166 ; d f=4 ; p<0.001)$ was induced by SUF exposure in the three highest treatment groups (Figure 1a). The maximum SOD activity was 2.3 times higher than that of the control, which was observed at both 2.96 and $8.3 \mu \mathrm{M}$ of SUF. SOD activity was also significantly induced $(F=63.6 ; d f=4 ; p<0.001)$ in $R$. subcapitata exposed to the highest concentrations (17 and $40.8 \mathrm{nM}$ ) of ERY (Figure 1b). The highest level of SOD activity was 2.1-fold higher than the control, being observed following exposure to $17 \mathrm{nM}$ of ERY. In CLA exposure, a significant increase $(F=23.9 ; d f=4 ; p<0.01)$ in SOD activity to 1.7-fold of the control was only noticeable at the highest exposure concentration (Figure 1c). Marked significant changes $(F=93.9 ; d f=4 ; p<0.001)$ in microalgal SOD activity were caused by CPX exposure. SOD activity level was maximum at $11.5 \mu \mathrm{M}$ of CPX and was 1.7fold higher than the control. However, SOD activity was significantly inhibited $(p<0.001)$ at 19.1 $\mu \mathrm{M}$ of the fluoroquinolone being 1.8 times lower than that of the control (Figure 1d).

\subsection{Effects of antibiotics on lipid peroxidation (LPO) levels}

Malondialdehyde, a routinely used index of LPO, was detected in the algal cells after $120 \mathrm{~h}$ of exposure to SUF, ERY, and CPX. SUF treatment at the concentration of $1.58 \mu \mathrm{M}$ did not increase the LPO level significantly $(p>0.05)$, while a significant increase and decrease $(p<$ 0.01) in LPO concentrations following exposure to $2.96-8.3 \mu \mathrm{M}$ and $0.24 \mu \mathrm{M}$ of SUF, respectively, were observed after $120 \mathrm{~h}$ (Figure 1e). The highest level of LPO was 2.5 times higher than that of the control and was observed at $2.96 \mu \mathrm{M}$ of the sulfonamide. The 
increases in LPO contents were not significant until $17 \mathrm{nM}$ of ERY $(p=0.13)$ or $11.5 \mu \mathrm{M}$ of CPX $(p=0.08)$ with both antibiotics significantly increasing LPO levels to 1.3 and 1.4-fold of the controls respectively at their highest concentrations of $40.8 \mathrm{nM}(F=9 ; d f=4 ; p<0.01)$ and $19.1 \mu \mathrm{M}(F=13.3 ; d f=4 ; p<0.001)$ respectively (Figure $1 \mathrm{f}$ and $1 \mathrm{~h}$ respectively). No significant changes $(F=0.77 ; d f=4 ; p>0.05)$ were seen in the LPO levels between the treatments and the control after $120 \mathrm{~h}$ exposure to CLA (Figure 1g).

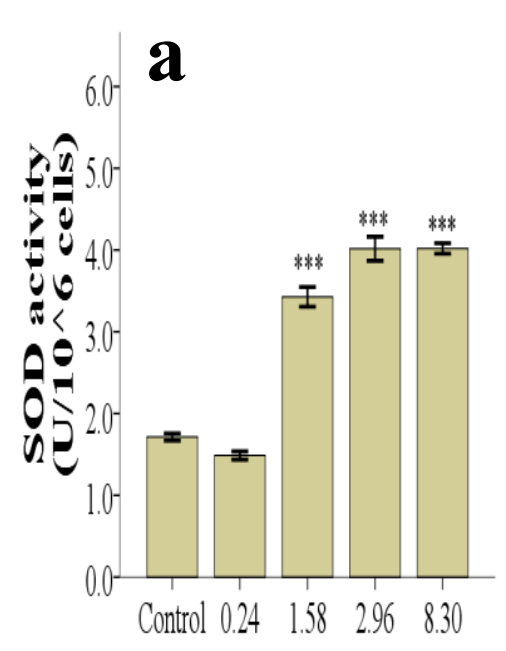

Concentration (uM)

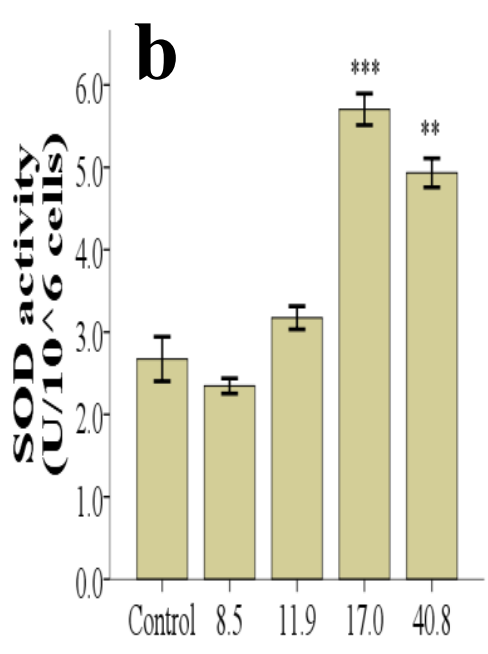

Concentration (nM)

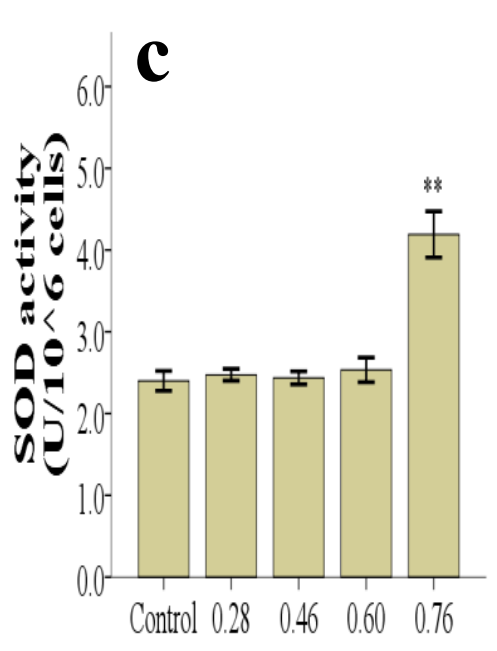

Concentration (nM)

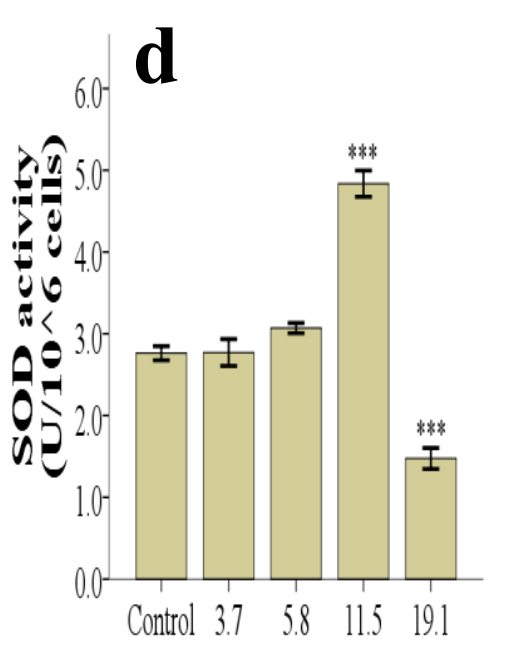

Concentration (uM)

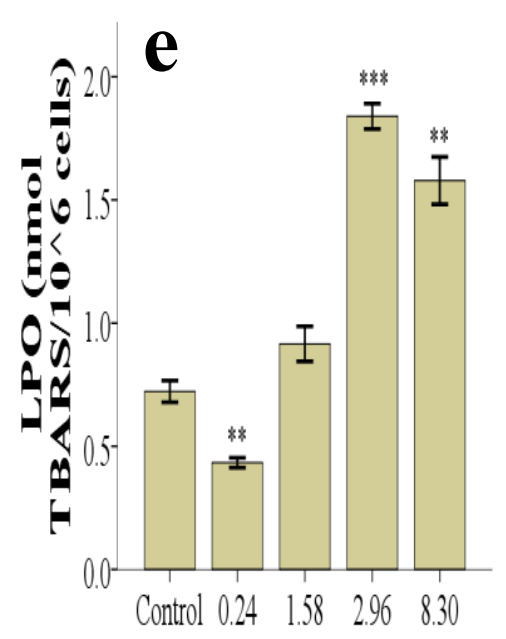

Concentration (uM)

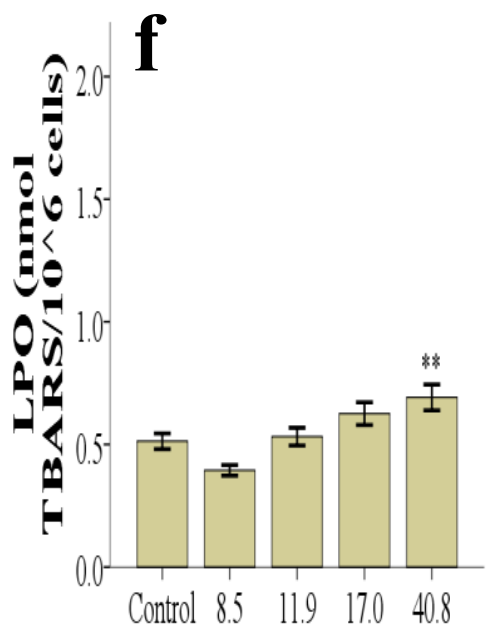

Concentration (nM)

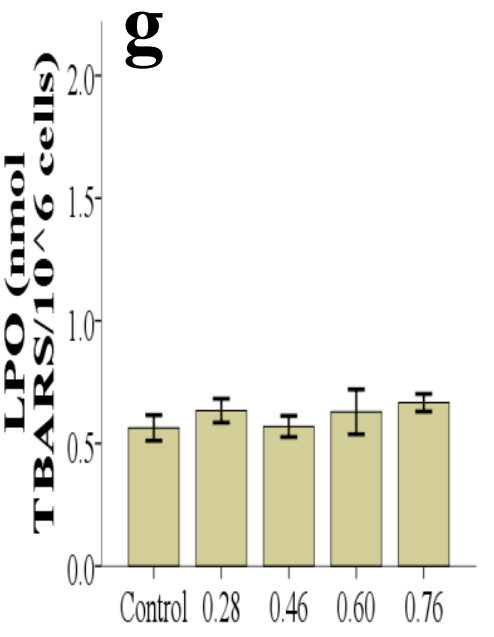

Concentration (nM)

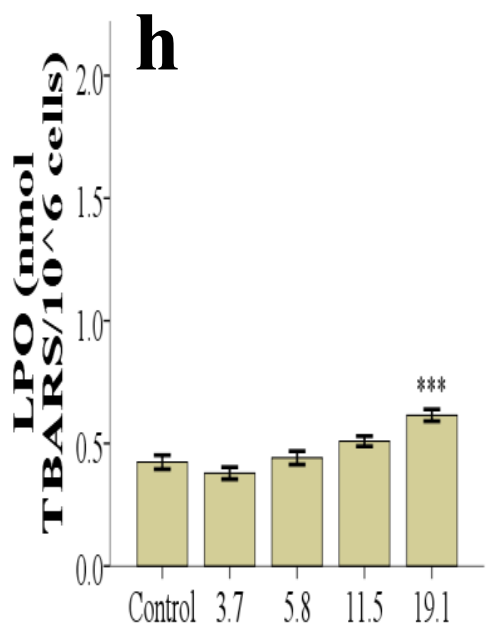

Concentration (uM) 
Figure 1. Oxidative stress responses in Raphidocelis subcapitata exposed to sulfamethoxazole (a \& e); erythromycin (b \& f); clarithromycin (c \& g); and ciprofloxacin (d $\&$ h) for 120 h. ${ }^{* *} p<0.01,{ }^{* * *} p<0.001$. Error bar represents SE of 6 to 7 replicates.

\subsection{Total energy content}

The individual energy reserve fractions of $R$. subcapitata were differentially affected by the antibiotics (Table 2). The average protein content $(F=10 ; d f=4 ; p<0.001)$, lipid content $(F=$ 20.9; $d f=4 ; p<0.001)$ and carbohydrate content $(F=6.9 ; d f=4 ; p<0.001)$ of $R$. subcapitata in this study were all significantly different from the controls at $0.24,2.96$ and $8.3 \mu \mathrm{M}$ of SUF. Significant inhibitory effect $(F=16.5 ; d f=4 ; p<0.001)$ on the total amount of energy available $(E a)$ was only observed at $0.24 \mu \mathrm{M}$ of the sulfonamide (Table 2).

Microalgal lipid content was not affected $(F=0.77 ; d f=4 ; p=0.55)$ by CLA exposure while average protein content $(F=2.8 ; d f=4 ; p<0.05)$ and carbohydrate content $(F=24 ; d f=4 ; p<$ 0.001 ) were significantly higher than the controls at $0.6 \mathrm{nM}$ and $0.28-0.46 \mathrm{nM}$ respectively of the macrolide (Table 2). However, these effects on the individual energy reserve fractions did not result in significant effects $(F=0.68 ; d f=4 ; p=0.60)$ on $E a$ (Table 2). ERY followed the same trend as CLA and had no effect $(F=2.2 ; d f=4 ; p=0.09)$ on the average lipid content of the algae while the protein content was significantly different $(F=24.3 ; d f=4 ; p<0.001)$ from that of the control at 11.9 and $17 \mathrm{nM}$ of ERY (Table 2). ERY caused a concentrationdependent significant decrease $(F=66.1 ; d f=4 ; p<0.001)$ in the average carbohydrate content of $R$. subcapitata, and the total energy content of $R$. subcapitata exposed to ERY was significantly higher $(F=7.9 ; d f=4 ; p<0.001)$ than the $E a$ in the control at $17 \mathrm{nM}$ (Table 2).

CPX treatment caused a significant increase $(F=3.1 ; d f=4 ; p<0.05)$ in protein content of $R$. subcapitata at $11.5 \mu \mathrm{M}$ and the average lipid content was significantly affected $(F=5.4 ; d f=$ 
$4 ; p<0.01$ ) by $3.7,5.8$ and $11.5 \mu \mathrm{M}$ treatments (Table 2 ). The algal carbohydrate content was significantly affected $(F=18.8 ; d f=4 ; p<0.001)$ by CPX exposure and was significantly lower than the control at the highest concentrations. The total energy content of CPX-exposed microalgae was higher than the $E a$ in control microalgae. This effect was significant $(F=7$; $d f=4 ; p<0.001)$ at 5.8 and $11.5 \mu \mathrm{M}$ of CPX (Table 2$)$.

Table 2. Energy reserve and total energy contents of Raphidocelis subcapitata after exposure to different antibiotics for $120 \mathrm{~h}$

\begin{tabular}{|c|c|c|c|c|}
\hline Drug & Protein & Lipid & Carbohydrate & $E a$ (Total energy) \\
\hline$\mu \mathrm{M}$ & \multicolumn{4}{|c|}{$\mathrm{mJ} / 10^{6}$ cells } \\
\hline \multicolumn{5}{|c|}{ Sulfamethoxazole } \\
\hline Control & $13089.2 \pm 568$ & $13534.9 \pm 846$ & $4727.8 \pm 195$ & $31351.9 \pm 1150$ \\
\hline 0.24 & $10443.7^{\mathrm{a}} \pm 859$ & $8233.8^{\mathrm{b}} \pm 542$ & $2484.3^{c} \pm 267$ & $21161.9^{c} \pm 1285$ \\
\hline 1.58 & $13389.5 \pm 1013$ & $15964.3 \pm 840$ & $4175.5 \pm 560$ & $33529.5 \pm 1269$ \\
\hline 2.96 & $10852.2 \pm 421$ & $18911.2^{\mathrm{b}} \pm 786$ & $4927.2 \pm 293$ & $34690.7 \pm 1055$ \\
\hline 8.30 & $7515.2^{c} \pm 697$ & $15519.9 \pm 1371$ & $4210.7 \pm 526$ & $27245.8 \pm 2085$ \\
\hline \multicolumn{5}{|c|}{ Erythromycin } \\
\hline Control & $5486.5 \pm 579$ & $6862.4 \pm 743$ & $3657.8 \pm 123$ & $16006.7 \pm 1086$ \\
\hline $8.00 \times 10^{-3}$ & $4551.6 \pm 227$ & $5571.1 \pm 501$ & $2628.6^{c} \pm 149$ & $12751.3 \pm 623$ \\
\hline $1.19 \times 10^{-2}$ & $8631.1^{a} \pm 660$ & $6639.7 \pm 427$ & $1469.7^{\mathrm{c}} \pm 45$ & $16740.5 \pm 797$ \\
\hline $1.70 \times 10^{-2}$ & $10452.8^{b} \pm 551$ & $7962.2 \pm 357$ & $1146.5^{c} \pm 110$ & $19561.6^{\mathrm{a}} \pm 810$ \\
\hline $4.08 \times 10^{-2}$ & $6298.4 \pm 377$ & $7243.6 \pm 843$ & $1213.5^{\mathrm{c}} \pm 207$ & $14755.7 \pm 1192$ \\
\hline \multicolumn{5}{|c|}{ Clarithromycin } \\
\hline Control & $6259.1 \pm 529$ & $8370.9 \pm 484$ & $528.3 \pm 57$ & $15158.4 \pm 891$ \\
\hline $2.8 \times 10^{-4}$ & $7100.1 \pm 585$ & $7965.9 \pm 311$ & $1337.4^{\mathrm{c}} \pm 101$ & $16403.4 \pm 887$ \\
\hline $4.6 \times 10^{-4}$ & $8244.2 \pm 819$ & $7250.5 \pm 583$ & $1355.1^{\mathrm{c}} \pm 71$ & $16849.8 \pm 1344$ \\
\hline $6.0 \times 10^{-4}$ & $9226.8^{a} \pm 862$ & $8011.8 \pm 491$ & $464.1 \pm 127$ & $17703.5 \pm 958$ \\
\hline $7.6 \times 10^{-4}$ & $6889.5 \pm 593$ & $8751.8 \pm 1042$ & $731.6 \pm 79$ & $16373.1 \pm 1243$ \\
\hline \multicolumn{5}{|c|}{ Ciprofloxacin } \\
\hline Control & $3555.7 \pm 247$ & $5384.1 \pm 312$ & $1413.7 \pm 96$ & $10353.6 \pm 492$ \\
\hline 3.7 & $4310.7 \pm 542$ & $7118.3^{b} \pm 216$ & $812.4^{\mathrm{c}} \pm 58$ & $12241.5 \pm 479$ \\
\hline
\end{tabular}




\begin{tabular}{lllll}
5.8 & $4395.4 \pm 474$ & $7655.8^{\mathrm{b}} \pm 560$ & $1724.3^{\mathrm{a}} \pm 88$ & $13775.6^{\mathrm{b}} \pm 747$ \\
11.5 & $6055.3^{\mathrm{b}} \pm 744$ & $6921.9^{\mathrm{a}} \pm 246$ & $1118.1^{\mathrm{a}} \pm 80$ & $14095.4^{\mathrm{b}} \pm 721$ \\
19.1 & $4238.9 \pm 505$ & $6290.8 \pm 200$ & $1093.6^{\mathrm{a}} \pm 75$ & $11623.4 \pm 534$ \\
\hline
\end{tabular}

${ }^{\mathrm{a}} p<0.05,{ }^{\mathrm{b}} p<0.01,{ }^{\mathrm{c}} p<0.001$, mean $\pm \mathrm{SE}$ of 6 to 7 replicates

\subsection{Energy consumption}

The $E_{c}$ was significantly affected by SUF exposure $(F=19.6 ; d f=4 ; p<0.001)$, decreasing at the lowest concentration, and increasing with the exposure concentrations (Figure 2a). Significant increases and decreases $(F=23.1 ; d f=4 ; p<0.001)$ in $E_{c}$ were observed at the highest (17 and $40.8 \mathrm{nM})$ and lowest $(8.5 \mathrm{nM})$ concentrations of ERY, respectively (Figure 2b) while CLA exposure, at the highest concentration, led to a significant increase $(F=21.7$; $d f=4 ; p<0.001)$ in $E_{c}$ (Figure $\left.2 \mathrm{c}\right)$. A significant increase $(F=55.6 ; d f=4 ; p<0.001)$ in microalgal $E_{c}$ was induced by CPX at 11.5 and $19.1 \mu \mathrm{M}$ (Figure $2 \mathrm{~d}$ ).

\subsection{Cellular energy allocation}

The cellular energy allocation (CEA) was used to estimate the overall energy budget of $R$. subcapitata, derived from the ratio of the available energy $E_{a}$ (sum of protein, sugar and lipid reserve) to the energy consumption $E_{c}$ (as derived from the ETS activity). Thus, a decline in CEA indicates a reduction in available energy or a higher energy expenditure, both resulting in a lower amount of energy available for growth or reproduction (Verslycke et al., 2004a). From this calculation, it was derived that $R$. subcapitata exposed to the highest concentrations of the individual antibiotics had a reduced CEA compared with the control microalgae. The CEA in $R$. subcapitata was significantly affected $(F=25.1 ; d f=4 ; p<0.001)$ by SUF at 2.96 and $8.3 \mu \mathrm{M}$ and the lowest CEA was 1.8-fold lower than the control (Figure $2 \mathrm{e})$. A significant reduction $(F=25.6 ; d f=4 ; p<0.001)$ in CEA was caused by ERY exposure 
at 17 and $40.8 \mathrm{nM}$ (Figure 2f). The lowest CEA, caused by $40.8 \mathrm{nM}$ of ERY, was 2.0 times lower than that of the control. CLA, at the highest concentration, significantly decreased $(F=$ 13.5; $d f=4 ; p<0.001$ ) CEA to 1.5 -fold of the control (Figure $2 \mathrm{~g}$ ). CEA in the microalgae was significantly affected $(F=11.1 ; d f=4 ; p<0.001)$ by CPX and it was 1.5 -fold lower and 1.3-fold higher than the control at the highest $(19.1 \mu \mathrm{M})$ and lowest $(3.7 \mu \mathrm{M})$ concentrations, respectively (Figure $2 \mathrm{~h}$ ). Table 3 shows a comparison between the 120 -h $\mathrm{EC}_{10}$ values for $\mathrm{CEA}$, cell yield and growth rate parameters. The $\mathrm{EC}_{10}$ values derived for both $\mathrm{CEA}$ and growth yield were similar for all the tested antibiotics while the CEA based $\mathrm{EC}_{10}$ values were much lower than the growth rate $\mathrm{EC}_{10}$ values. The $\mathrm{CEA}$-based $\mathrm{EC}_{10}$ for $\mathrm{SUF}$ was 1.5 times lower than the growth yield-based $\mathrm{EC}_{10}$ threshold while for $\mathrm{ERY}$, the cellular-based $\mathrm{EC}_{10}$ value was 1.08 times lower than the organism-based $\mathrm{EC}_{10}$. For CLA, the CEA-based $\mathrm{EC}_{10}$ was 1.04 times higher than the $\mathrm{EC}_{10}$ value of growth yield, while for $\mathrm{CPX}$, the net energy budget $\mathrm{EC}_{10}$ value was 1.09-fold higher than its growth yield $\mathrm{EC}_{10}$.

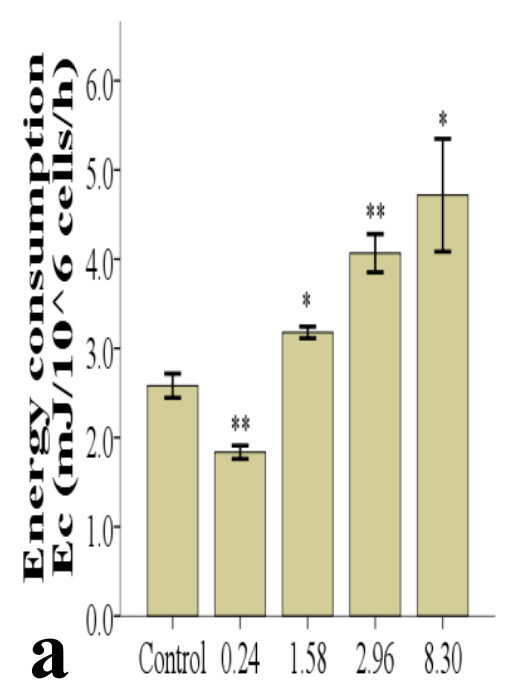

Concentration (uM)

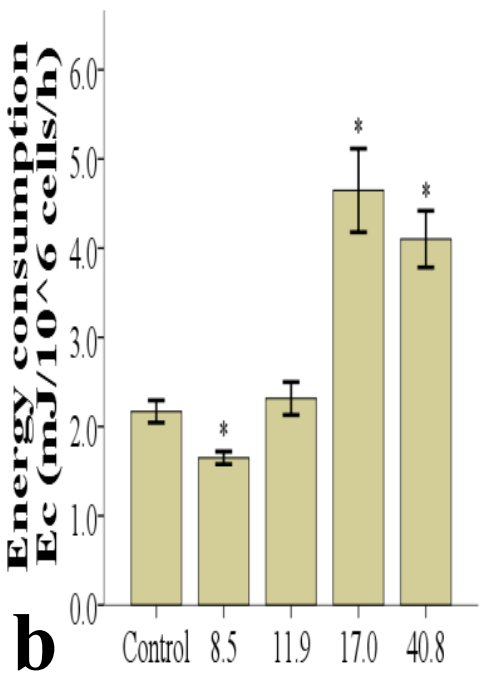

Concentration (nM)

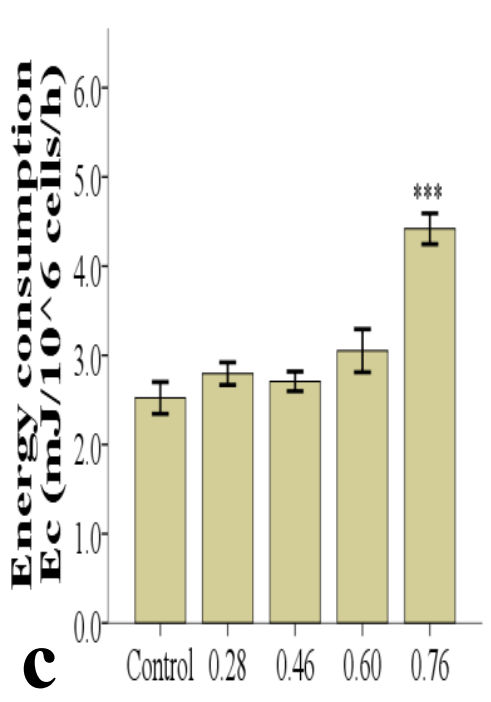

Concentration (nM)

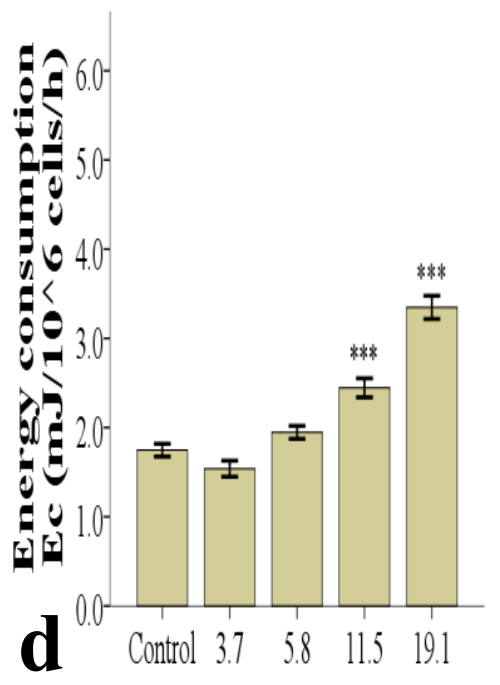

Concentration (uM)

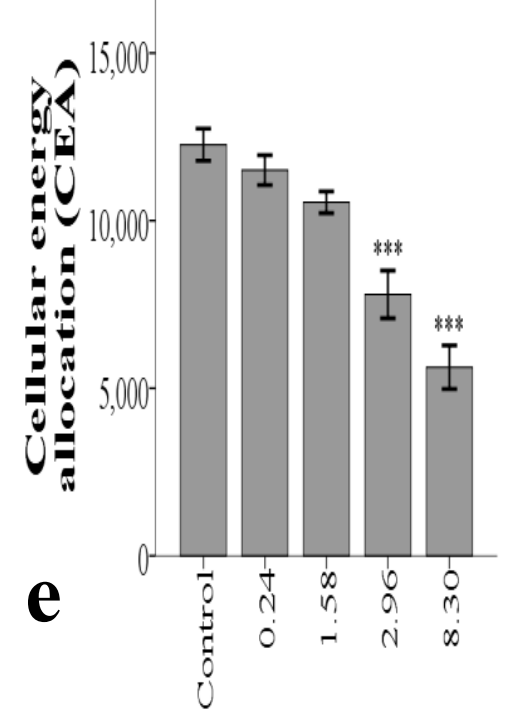

Concentration (uM)

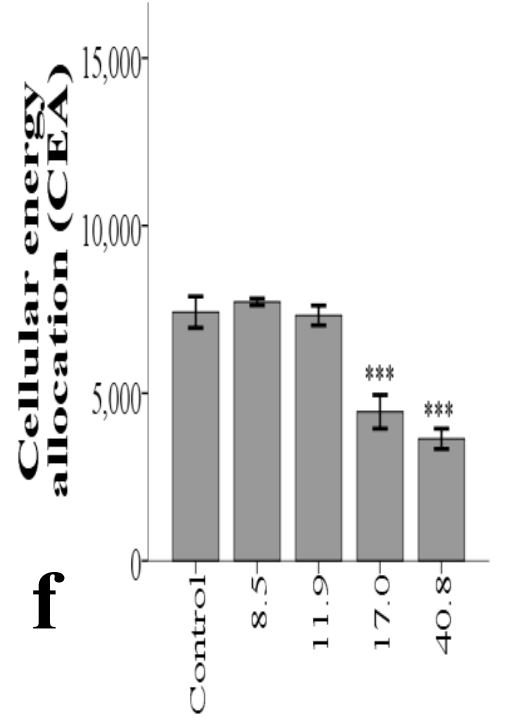

Concentration (nM)

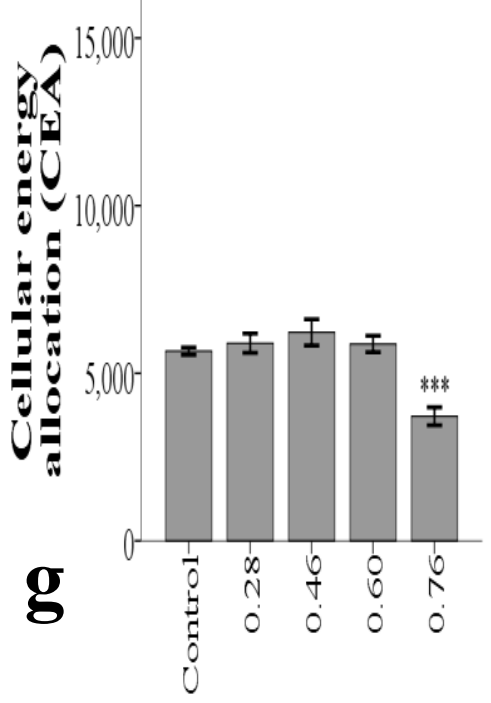

Concentration (nM)

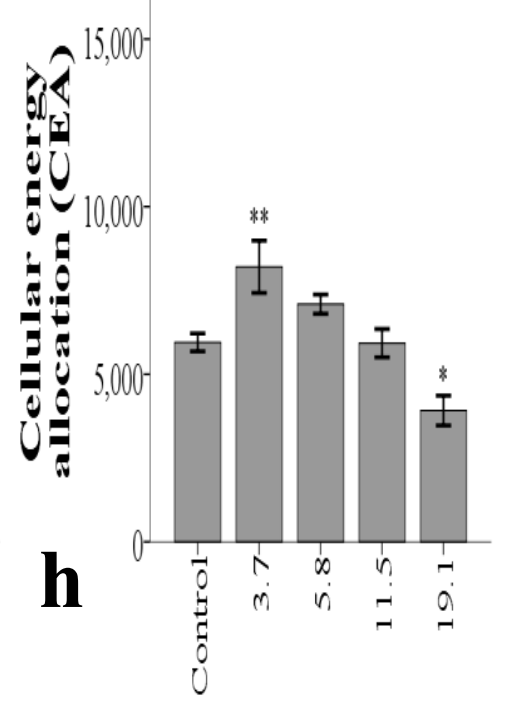

Concentration (uM) 
Figure 2. Energy consumption and cellular energy allocation changes in Raphidocelis subcapitata following $120 \mathrm{~h}$ exposure to sulfamethoxazole (a \& e); erythromycin (b \& f); clarithromycin (c \& g); and ciprofloxacin (d \& h). ${ }^{*} p<0.05$, ${ }^{* *} p<0.01,{ }^{* * *} p<0.001$. Error bar represents SE of 6 to 7 replicates.

Table 3. $120 \mathrm{~h} \mathrm{EC}_{10}$ values $(\mu \mathrm{M})$ for CEA, growth yield, and growth rate

\begin{tabular}{llll}
\hline Chemical & CEA $\left(\mathrm{EC}_{10}\right)$ & Growth yield $\left(\mathrm{EC}_{10}\right)$ & Growth rate $\left(\mathrm{EC}_{10}\right)$ \\
\hline Sulfamethoxazole & 0.90 & 1.37 & 2.57 \\
Erythromycin & 0.013 & 0.014 & 0.031 \\
Clarithromycin & 0.00065 & 0.00062 & $>0.00076$ \\
Ciprofloxacin & 13.53 & 12.38 & 18.33 \\
\hline
\end{tabular}

\subsection{Correlation between the various parameters measured in $R$. subcapitata}

The correlation matrices depicting the strength of the linear relationship between the various parameters or endpoints measured in this study are shown in Tables 4 and 5. A strong positive correlation between the two growth response variables, percent inhibition of cell yield $\left(\% \mathrm{I}_{\mathrm{y}}\right)$ and growth rate $\left(\% \mathrm{I}_{\mathrm{r}}\right)$ inhibition, was obtained for all the pharmaceuticals. For SUF, both growth parameters had strong positive correlations with SOD activity and LPO while correlation with CEA was not significant. While the growth response variables correlated strongly with LPO and CEA for CPX and ERY, only $\% \mathrm{I}_{\mathrm{y}}$ correlated significantly with SOD for ERY (Tables 4, 5). Significant positive and negative correlations were obtained between the growth parameters $\left(\% \mathrm{I}_{\mathrm{y}} \& \% \mathrm{I}_{\mathrm{r}}\right)$ and SOD activity and CEA, respectively, for CLA. There was a strong positive correlation between LPO and SOD activity for SUF and ERY. The negative or indirect correlation between SOD activity and CEA was significant for SUF, ERY, and CLA. A strong negative correlation between LPO and CEA was shown for 
SUF, CPX, and ERY. CEA significantly correlated with all the measured parameters in ERY exposure only (Table 5).

Table 4. Correlation between parameters measured after sulfamethoxazole and ciprofloxacin exposures for 120 $\mathrm{h}$

\begin{tabular}{|c|c|c|c|c|c|c|c|c|c|c|c|}
\hline & Conc & $\% \mathrm{I}_{\mathrm{y}} \mathrm{S}$ & $\% \mathrm{I}_{\mathrm{y}} \mathrm{X}$ & $\% \mathrm{I}_{\mathrm{r}} \mathrm{S}$ & $\% \mathrm{I}_{\mathrm{r}} \mathrm{X}$ & SodS & SodX & LpoS & LpoX & CeaS & CeaX \\
\hline$\% \mathrm{I}_{\mathrm{y}} \mathrm{S}$ & 0.66 & 1 & & & & & & & & & \\
\hline$\% \mathrm{I}_{\mathrm{y}} \mathrm{X}$ & $0.85^{\mathrm{a}}$ & - & 1 & & & & & & & & \\
\hline$\% \mathrm{I}_{\mathrm{r}} \mathrm{S}$ & 0.70 & $0.99^{\mathrm{b}}$ & - & 1 & & & & & & & \\
\hline$\% \mathrm{I}_{\mathrm{r}} \mathrm{X}$ & $0.87^{\mathrm{a}}$ & - & $0.99^{\mathrm{b}}$ & - & 1 & & & & & & \\
\hline SodS & 0.75 & $0.91^{\mathrm{a}}$ & - & $0.94^{\mathrm{b}}$ & - & 1 & & & & & \\
\hline SodX & -0.21 & - & -0.33 & - & -0.4 & - & 1 & & & & \\
\hline LpoS & 0.71 & $0.86^{\mathrm{a}}$ & - & $0.89^{\mathrm{a}}$ & - & $0.90^{\mathrm{a}}$ & - & 1 & & & \\
\hline LpoX & $0.93^{\mathrm{b}}$ & - & $0.97^{\mathrm{b}}$ & - & $0.98^{\mathrm{b}}$ & - & -0.26 & - & 1 & & \\
\hline CeaS & $-0.95^{\mathrm{b}}$ & -0.72 & - & -0.77 & - & $-0.85^{\mathrm{a}}$ & - & $-0.86^{\mathrm{a}}$ & - & 1 & \\
\hline CeaX & -0.73 & - & $-0.98^{\mathrm{b}}$ & - & $-0.96^{b}$ & - & 0.34 & - & $-0.92^{\mathrm{a}}$ & - & 1 \\
\hline
\end{tabular}

$\mathrm{S} \& \mathrm{X}=$ sulfamethoxazole and ciprofloxacin respectively.

Conc: pharmaceutical concentrations (actual); $\% \mathrm{I}_{\mathrm{y}} \mathrm{S} \& \% \mathrm{I}_{\mathrm{y}} \mathrm{X}$ : percent growth yield inhibition; $\% \mathrm{I}_{\mathrm{r}} \mathrm{S} \& \% \mathrm{I}_{\mathrm{r}} \mathrm{X}$ : percent growth rate inhibition; SodS \& SodX: superoxide dismutase activity; LpoS \& LpoX: lipid peroxidation; CeaS \& CeaX: cellular energy allocation. Correlation is significant at ${ }^{\mathrm{a}} p<0.05,{ }^{\mathrm{b}} p<0.01$. 
Table 5. Correlation between parameters measured after erythromycin and clarithromycin exposures for $120 \mathrm{~h}$

\begin{tabular}{|c|c|c|c|c|c|c|c|c|c|c|c|}
\hline & Conc & $\% \mathrm{I}_{\mathrm{y}} \mathrm{E}$ & $\% \mathrm{I}_{\mathrm{y}} \mathrm{C}$ & $\% \mathrm{I}_{\mathrm{r}} \mathrm{E}$ & $\% \mathrm{I}_{\mathrm{r}} \mathrm{C}$ & SodE & SodC & LpoE & LpoC & CeaE & $\mathrm{CeaC}$ \\
\hline$\% \mathrm{I}_{\mathrm{y}} \mathrm{E}$ & $0.90^{\mathrm{a}}$ & 1 & & & & & & & & & \\
\hline$\% \mathrm{I}_{\mathrm{y}} \mathrm{C}$ & 0.75 & - & 1 & & & & & & & & \\
\hline$\% \mathrm{I}_{\mathrm{r}} \mathrm{E}$ & $0.92^{\mathrm{a}}$ & $0.99^{\mathrm{b}}$ & - & 1 & & & & & & & \\
\hline$\% \mathrm{I}_{\mathrm{r}} \mathrm{C}$ & 0.74 & - & $1.00^{\mathrm{b}}$ & - & 1 & & & & & & \\
\hline SodE & 0.67 & $0.81^{\mathrm{a}}$ & - & 0.77 & - & 1 & & & & & \\
\hline SodC & 0.68 & - & $0.99^{\mathrm{b}}$ & - & $0.99^{\mathrm{b}}$ & - & 1 & & & & \\
\hline LpoE & 0.77 & $0.96^{\mathrm{b}}$ & - & $0.94^{\mathrm{b}}$ & - & $0.87^{\mathrm{a}}$ & - & 1 & & & \\
\hline LpoC & 0.70 & - & 0.76 & - & 0.76 & - & 0.71 & - & 1 & & \\
\hline CeaE & $-0.85^{\mathrm{a}}$ & $-0.93^{\mathrm{a}}$ & - & $-0.92^{\mathrm{a}}$ & - & $-0.94^{b}$ & - & $-0.91^{\mathrm{a}}$ & - & 1 & \\
\hline $\mathrm{CeaC}$ & -0.53 & - & $-0.95^{\mathrm{b}}$ & - & $-0.96^{\mathrm{b}}$ & - & $-0.97^{b}$ & - & -0.67 & - & 1 \\
\hline
\end{tabular}

$\mathrm{E} \& \mathrm{C}=$ erythromycin and clarithromycin respectively

Conc: pharmaceutical concentrations (actual); $\% \mathrm{I}_{\mathrm{y}} \mathrm{E} \& \% \mathrm{I}_{\mathrm{y}} \mathrm{C}$ : percent growth yield inhibition; $\% \mathrm{I}_{\mathrm{r}} \mathrm{E} \& \% \mathrm{I}_{\mathrm{r}} \mathrm{C}$ : percent growth rate inhibition; SodE \& SodC: superoxide dismutase; LpoE \& LpoC: lipid peroxidation; CeaE \& CeaC: cellular energy allocation. Correlation is significant at ${ }^{\mathrm{a}} p<0.05,{ }^{\mathrm{b}} p<0.01$. 


\section{Discussion}

The lowest observed growth yield inhibitory concentrations (LOECs) of ERY (17 nM), CLA $(0.76 \mathrm{nM})$, and CPX $(19.1 \mu \mathrm{M})$ obtained in this study (Table 1) are environmentally realistic as these antibiotics have been measured up to the maximum levels of $122 \mathrm{nM}, 0.48 \mathrm{nM}$, and 19.6 $\mu \mathrm{M}$ respectively in surface water (LfU, 2009; UBA 2010; Hughes et al., 2013; Baumann et al., 2015). The growth yield and rate inhibition of $R$. subcapitata strongly correlated with the exposure concentrations of ERY and CPX after $120 \mathrm{~h}$ while correlation was not significant for CLA and SUF concentrations (Tables 4 and 5). This may be due to the instability or significant decrease in the concentrations of the antibiotics in the test systems caused by degradation, uptake or other reasons. The observation of hormetic effects in the test microalgae in this study at low concentrations of the antibiotics have been reported in literature (Soto et al., 2011). The macrolides (CLA and ERY) were the most toxic to growth in this study (Table 1) and they have been reported to be highly toxic to the afore-mentioned alga (Yang et al., 2008; Liu et al., 2011; Gonzalez-Pleiter, 2013; Villian et al., 2016).

Both animal and plant cells can generate, via oxidative metabolism, a number of different reactive oxygen species (ROS), including the superoxide anion $\left(\mathrm{O}_{2}^{-}\right)$, hydrogen peroxide $\left(\mathrm{H}_{2} \mathrm{O}_{2}\right)$ and singlet oxygen $\left(\mathrm{O}_{2}\right)$ and by Fenton reaction, the hydroxyl radical $(\mathrm{OH})(\mathrm{Halliwell}$ and Gutteridge, 2007). Although many ROS generating processes are slow under normal conditions, these processes can be accelerated by xenobiotics (Torres et al., 2008). All ROS are harmful to organisms at high concentrations (Apel and Hirt, 2004). The mitochondria and chloroplasts of photosynthesizing organisms are simultaneously sources and targets of oxidative injury due to the intense electron flux in their microenvironment. This is caused by the presence of elevated oxygen and high metal ion concentrations (Couee et al., 2006).

Aerobic organisms express a battery of antioxidative enzymes that contribute to the control of cellular ROS levels and several papers have described the effects of antibiotics on algae (Nie et al., 2007; Liu et al., 2012). Superoxide dismutase (SOD) is the cell's first line of defense against ROS by catalysing the disproportionation of $\mathrm{O}_{2}^{-}$to $\mathrm{O}_{2}$ and $\mathrm{H}_{2} \mathrm{O}_{2}$ (Ken et al., 2005; Sun et al., 2017). Since $\mathrm{O}_{2}{ }^{-}$is a precursor to several other highly reactive species, control of this free radical concentration by SOD constitutes an important protective mechanism in algae (Fridovich, 1997). In this work, effects of antibiotic stress on $R$. subcapitata at the cellular level were addressed. The activity of SOD in the microalgae was induced at 
concentrations of SUF $(1.58-8.3 \mu \mathrm{M})$, ERY $(17-40.8 \mathrm{nM})$, and CLA $(0.76 \mathrm{nM})$ toxic to growth and at CPX concentration $(11.5 \mu \mathrm{M})$ non-toxic to growth. The macrolide, ERY had the most effect on SOD activity in this study followed by CPX. Nie et al. (2013) reported a significant induction in SOD activity of $R$. subcapitata at similar SUF concentrations (1.97, 5.92-9.88 $\mu \mathrm{M})$ as this study but at higher ERY concentrations (81.7-408.7 $\mathrm{nM}$ ) and lower CPX levels (4.5-7.5 $\mu \mathrm{M})$.

The enhanced SOD activity in medium to high concentrations of SUF and ERY in this study suggests that a higher antioxidative capacity is necessary for $R$. subcapitata to scavenge ROS when the algae is exposed to the antibiotics. The elevated activity of SOD in the algae at CPX concentration non-toxic to growth agrees with the findings of Kurama et al. (2002), that overproduction of SOD is the main mechanism for protecting plant chloroplasts against organic pollution. The substantial decline in SOD activity at the highest concentration of CPX may be attributed to the high accumulation of the superoxide radical, derived from an imbalance between the rates of detoxification and production of $\mathrm{O}_{2}^{-}$and exceeding the capacity of SOD to respond to the radical levels.

Superfluous ROS can react with lipids, proteins, or nucleic acids and cause irreversible oxidative damage (Sies, 1997). In this study, all antibiotics except CLA induced damage to lipids in $R$. subcapitata with its LPO content increasing significantly at $2.96-8.3 \mu \mathrm{M}, 19.1$ $\mu \mathrm{M}$, and $40.8 \mathrm{nM}$ of SUF, CPX, and ERY, respectively, with SUF causing the highest damage to lipid. Nie et al. (2013) found similar results when addressing malondialdehyde levels, a routinely used index of LPO, and these levels increased in R. subcapitata after a 96$\mathrm{h}$ exposure to 5.92-9.88 $\mu \mathrm{M}$ SUF, 81.7-408.7 nM ERY, and 3-7.5 $\mu \mathrm{M}$ CPX.

In this present study, it was found that the activity of antioxidant SOD was induced at some of the exposure concentrations to resist oxidative insult. The degree of oxidative damage is decided by the balance between ROS and antioxidants production (Jubany-Mari et al., 2010), and could also be shown by the tested proxy, the LPO levels (Qian et al., 2011). Consequently, the elevated LPO concentration observed at the highest concentration of CPX in this study strongly correlates with the decline in SOD activity in the microalga. In addition, the high LPO levels in $R$. subcapitata following exposure to growth inhibitory levels of SUF and ERY suggests that the increase in SOD activity or increased antioxidant responses was not enough to counteract the accumulation of ROS and prevent oxidative damage. This is 
further supported by the strong linear relationships between the individual growth markers and SOD/LPO (Tables 4 and 5).

To the best of our knowledge, this is the first report to investigate the effect of pharmaceuticals on the cellular energy allocation changes in microalgae. As a result, findings from this study could only be compared with other studies carried out using aquatic invertebrates. Significant effects $(p<0.05)$ on the energy available or acquisition of the microalgae were observed following antibiotic treatment. However, the available energy $(E a)$ as a parameter does not seem to be a good indicator of the organisms' physiological status, since little variation in energy content and absence of concentration-dependent responses were observed. A higher protein, lipid, and carbohydrate contents as well as a higher Ea were observed in the microalgae at some of the high concentrations of the antibiotics than in the control microalgae in this study. The only exception was the concentration-dependent reduction in carbohydrate content following ERY exposure. The accumulation of energy reserves in green algae as responses to environmental stressors have been reported in literature (Cheng and He, 2014; Paes et al., 2016). Mysids exposed to the pesticide chlorpyrifos for $48 \mathrm{~h}$ were found to have a significantly higher protein, lipid, and total energy content at the highest concentrations than the control mysids (Verslycke et al., 2004b). The reason behind this observation is not clearly understood and may possibly be due to the need for the algae to counteract either the decline in other energy fractions or the increase in energy expenditure.

The results from this study clearly show that the antibiotic exposures induced concentrationdependent significant effects on the energy expenditure $\left(E_{c}\right)$ of $R$. subcapitata. Growth yield inhibitory concentrations of SUF (18.6-30.3\%), CLA (28.7\%), ERY (16.9-39.2\%) and CPX (28.2\%) elicited a considerable increase in the energy consumption of the microalgae which was responsible for the significant decline in the CEA observed in this study. It was also reported by Verslycke et al. (2004b) that the significant decrease in CEA in chlorpyrifosexposed mysids was caused by the increase in the energy consumption of the mysids. The stimulatory effect on microalgal growth yield (up to 16\%) observed at the lowest CPX concentration also highly correlated with the increase in the net energy budget (CEA) (Table 1). The elevated Ec reported at some of the inhibitory levels of the antibiotics may be attributed to the need for the microalgae to respond to oxidative stress under these conditions, given the significant increases in SOD activity. Based on CEA based $\mathrm{EC}_{10}$ values and also in 
agreement with toxicity exerted towards growth, CEA in $R$. subcapitata was affected by the antibiotics in the following order: CLA $>$ ERY $>$ SUF $>$ CPX.

The decline in CEA obtained in this study signifies a lower amount of energy available for algal growth or cell division and explains the significant growth yield inhibitory effects of the antibiotics. In addition, pearsons correlation analysis between the CEA parameter and the other endpoints reveals a significant $(p<0.05)$ linear relationship between the CEA results and organismal level effects except in SUF exposure where correlation was moderate. Coefficients of correlation $\left(\mathrm{r}^{2}\right)$ between CEA values and $\% \mathrm{I}_{\mathrm{y}} / \% \mathrm{I}_{\mathrm{r}}$ were $-0.98 /-0.96 ;-0.93 /-$ 0.92; -0.95/-0.96 and -0.72/-0.77 for CPX, ERY, CLA, and SUF, respectively. Likewise, apart from CLA, a strong indirect correlation was found between the CEA responses and oxidative stress biomarker (LPO) in this study. De Coen and Janssen (1997) also reported a strong linear correlation between CEA parameter and a population level effect (intrinsic rate of natural increase) in Daphnia magna exposed to lindane and mercury. It was concluded that such high correlations demonstrate the possibility of linking energy-based suborganismal effect criteria with effects emerging at the higher levels of biological continnum (De Coen and Janssen, 1997).

Based on the LOECs and NOECs obtained in this study, only the LPO agreed with the growth rate responses for all the antibiotics while the Ec, CEA, and SOD responses were more sensitive than the growth rate responses for all the tested antibiotics. These corroborate the theory of higher sensitivities of endpoints at a lower level of biological organization (Verslycke et al., 2004b) and suggests that the use of cellular/molecular biomarkers can be more sensitive and more informative than some organismal level effects (e.g. growth rate) in monitoring the impact of pharmaceuticals in microalgal aquatic ecosystems. The biochemical responses of CEA have also been found to be more sensitive than organismal responses in chlorpyrifos-exposed mysids (Verslycke et al., 2004b).

The use of NOECs and LOECs has been faulted by some researchers and the regressionbased approach has been suggested as an alternative method to estimate low toxic effect levels (Suter, 1996). The generation of similar toxicity threshold values for CEA and growth yield responses (Table 3), suggests CEA as a reliable indicator of the physiological status of $R$. subcapitata, and the energy budget model could be useful in monitoring the health of the bioindicator algal species in the aquatic ecosystem. CEA also exhibited much lower $\mathrm{EC}_{10}$ 
values than the growth rate in this study, an indication that it is more sensitive and reliable as an indicator of toxic effects in green algae.

\section{Conclusions}

In summary, exposure to the antibiotics caused significant effects on the growth or physiology of $R$. subcapitata, which were detected at cellular levels of biological organization by biochemical biomarkers such as SOD, LPO, Ec, and CEA, used in this study. These lower tier endpoints provided information on the various mechanisms of toxicity of the tested antibiotics. The decline in microalgal CEA caused by a considerable increase in Ec elucidates the growth inhibitory effects seen at the organismal level. CEA generated similar toxicity threshold values as the growth yield responses, thus stimulating its use as an alternative or complementary approach in measuring the physiological aberrations in microalgae exposed to pharmaceuticals. In addition, SOD, $E c$, and CEA were more sensitive than the classical endpoint of growth rate for all the antibiotics in this study. However, more work is required to determine whether these endpoints would provide a consistent response to a wide range of antibiotics or pharmaceuticals. To avoid the underestimation of pharmaceutical effects in the aquatic ecosystem, relevant water regulation authorities should 
consider the integration of these more sensitive, informative and proactive models into the risk assessment of pharmaceuticals.

\section{Acknowledgements}

This work was partly funded by the EU Transnational Territorial Cooperation programme INTERREG IVB NWE projects (PILLS project 008B \& "noPILLS in our waters"); and A. Aderemi was also funded by a PhD studentship from SEBE, Glasgow Caledonian University. This study also had the support of the Fundação para a Ciência e a Tecnologia (FCT) Strategic Project UID/MAR/04292/2013 granted to MARE, project ProTEoME - PROteomic Tools to assess Endocrine disruptiOn MEchanisms ((PTDC/AAG-MAA/1302/2014), and the post-doc grant to Sara C. Novais (SFRH/BPD/94500/2013). The project was also partially funded by the Integrated Programme of SR\&TD "SmartBioR" (reference Centro-01-0145FEDER-000018) cofunded by Centro 2020 program, Portugal2020, European Union, through the European Regional Development Fund.

\section{References}

Apel, K., Hirt, H.V., 2004. Reactive oxygen species: metabolism, oxidative stress, and signal transduction. Annual Review of Plant Biology 55: pp.373-399.

Baumann, M., Weiss, K., Maletzki, D., Schussler, W., Schudoma, D., Kopf W., Kuhnen, U., 2015. Aquatic toxicity of the macrolide antibiotic clarithromycin and its metabolites. Chemosphere 120: pp.192-198.

Besse, J.P., Garric, J., 2008. Human pharmaceuticals in surface waters implementation of a prioritization methodology and application to the French situation. Toxicological Letter 176: pp.104-123.

Bird, R.P., Draper, A.H., 1984. Comparative studies on different methods of malondialdehyde determination. Methods in Enzymology 90: pp.105-110. 
Bligh, E.G., Dyer, W.J., 1959. A rapid method of total lipid extraction and purification. Canadian Journal of Biochemistry and Physiology 37: pp.911-917.

Bradford, M.M., 1976. A rapid and sensitive method for the quantitation of microgram quantity of protein utilizing the principle of protein-dye binding. Analytical Biochemistry 72: pp.248-254.

Cheng, D., He, Q., 2014. Assessment of environmental stresses for enhanced microalgal biofuel production - an overview. Frontiers in Energy Research. doi: 10.3389/fenrg.2014.00026.

Connon, R.E., Geist, J., Werner, I., 2012. Effect-based tools for monitoring and predicting the ecotoxicological effects of chemicals in the aquatic environment: Review, Sensors, 12: pp.12741-12771.

Couee, I., Sulmon, C., Gouesbet, G., Amrani, A., 2006. Involvement of soluble sugars in reactive oxygen species balance and responses to oxidative stress in plants. Journal of Experimental Botany 57: pp.449-459.

De Coen, W.M., Janssen, C.R., Persoone, G., 1995. Biochemical assessment of cellular energy allocation in Daphnia magna exposed to toxic stress as an alternative to the conventional "scope for growth" methodology. Proceedings, International Symposium on Biological Markers of Pollution, Chinon, France, September 21-22, pp.163-170.

De Coen, W.M., Janssen, C.R., 1997. The use of biomarkers in Daphnia magna toxicity testing. IV. Cellular energy allocation: A new biomarker to assess the energy budget of toxicant-stressed Daphnia populations. Journal of Aquatic Ecosystem Stress and Recovery 6: pp.43-55.

De Coen, W.M., Janssen, C.R., 2003a. The missing biomarker link: Relationships between effects on the cellular energy allocation biomarker of toxicant-stressed Daphnia magna and corresponding population characteristics. Environmental Toxicology and Chemistry 22(7): pp.1632-1641. 
De Zwart, L., Meerman, J.C., Vermeulen, N., 1999. Biomarkers of free radical damage: Applications in experimental animals and in humans. Free Radical Biology and Medicine 26: pp.202-226.

Ferreira Nuno, G.C., Morgado, R., Santos Miguel, J.G., Soares Amadeu, M.V.M., Loureiro, S., 2015. Biomarkers and energy reserves in the isopod Porcellionides pruinosus: The effects of long-term exposure to dimethoate. Science of the Total Environment 502: pp.91-102.

Fridovich, I., 1997. Superoxide anion radical, superoxide dismutases, and related matters. Journal of Biological Chemistry 250: pp.18515-18517.

Gil, F., Pla, A., 2001. Biomarkers as biological indicators of xenobiotic exposure: a review. Journal of Applied Toxicology 21: pp.245-255.

Gnaiger, E., 1983. Calculation of energetic and biochemical equivalents of respiratory oxygen consumption. In Gnaiger E, Forstner H, eds, Polarographic Oxygen Sensors. Aquatic and Physiological Applications. Springer Verlag, Berlin, Germany, pp.337-345.

Gonzalez-Pleiter, M., Gonzalo, S., Rodea-Palomares, I., Leganes, F., Rosal, R., Boltes, K., Marco, E., Fernandez-Pinas, F., 2013. Toxicity of five antibiotics and their mixtures towards photosynthetic aquatic organisms: implications for environmental risk assessment. Water Research 47: pp.2050-2064.

Gullberg, E., Cao, S., Berg, O.G., Ilback, C., Sandegren, L., Hughes, D., Andersson D.I., 2011. Selection of resistant bacteria at very low antibiotic concentrations. PLoS Pathogens 7(7): e1002158. doi: 10.1371/journal.ppat.1002158

Halling-Sorensen, B., Nors Nielsen, S., Lanzky, P.F., Ingerslev, F., Holten Lutzhoft, H.C., Jorgensen, S.E., 1998. Occurrence, fate and effects of pharmaceuticals substances in the environment- a review. Chemosphere 36(2): pp.357-393.

Halliwell, B., Gutteridge, J.M.C., 2007. Free radicals in biology and medicine, $4^{\text {th }}$ Ed. Oxford University Press, New York, 704pp.

Helwig, K., Hunter, C., MacLachlan, J., McNaughtan, M., Roberts, J., Cornelissen, A., Dagot, C., Evenblij, H., Klepiszewski, K., Lyko, S., Nafo, I., McArdell, C.S., Venditti, S., Pahl, O., 2013. Micropollutant point sources in the built environment: identification and 
monitoring of priority pharmaceutical substances in hospital effluents. Journal of Environmental and Analytical Toxicology 3: 177. doi: 10.4172/2161 - 0525.1000177.

Hernando, M.D., Mezcua, M., Fernandez-Alba, A.R., Barcelo, D., 2006. Environmental risk assessment of pharmaceutical residues in wastewater effluents, surface waters and sediments. Talanta 69: pp.334-342.

Huggett, R.J., Kimerly, R.A., Mehrle, P.M., Jr. Bergman, H.L., 1992. Biomarkers: Biochemical, Physiological and Histological Markers of Anthropogenic Stress; Lewis Publishers: Chelsea, MI, USA

Hughes, S.R., Kay, P., Brown, L.E., 2013. Global synthesis and critical evaluation of pharmaceutical data sets collected from river systems. Environmental Science and Technology 47: pp.661-677.

ISD Scotland, 2017. Prescribing and medicines: Dispenser remuneration and prescription cost analysis 2016/2017. Retrieved on $18^{\text {th }}$ April 2017 from http://www.isdscotland.org/HealthTopics/Prescribing-and-Medicines/Community-Dispensing/Dispenser-Remuneration/

Johnson, A.C., Keller, V., Dumont, E., Sumpter, J.P., 2015. Assessing the concentrations and risks of toxicity from antibiotics ciprofloxacin, sulfamethoxazole, trimethoprim and erythromycin in European rivers. Science of the Total Environment 511: pp.747-755.

Jones, O.A., Voulvoulis, N., Lester, J.N., 2002. Aquatic environmental assessment of the top 25 English prescription pharmaceuticals. Water Research 36: pp.5013-5022.

Jubany-Mari, T., Munne-Bosch, S., Alegre, L., 2010. Redox regulation of water stress responses in field-grown plants. Role of hydrogen peroxide and ascorbate. Plant Physiology and Biochemistry 48: pp.351-358.

Ken, C.F., Hsiung, T.M., Huang, Z.X., Juang, R.H., Lin, C.T., 2005. Characterization of the Fe/Mn-superoxide dismutase from diatom (Thallassiosira weissflogii): cloning, expression and property. Journal of Agricultural and Food Chemistry 9: pp.1470-1474. 
King, F.D., Packard, T.T., 1975. Respiration and the activity of the respiratory electron transport system in marine zooplankton. Limnology and Oceanography 20: pp.849-854.

Kummerer, K., 2009. Antibiotics in the aquatic environment - a review, Part I. Chemosphere 75: pp.417-434.

Kurama, E.E., Fenille, R.C., Rosa, Jr V.E., Rosa, D.D., Ulian, E.C., 2002. Mining the enzymes involved in the detoxification of reactive oxygen species (ROS) in sugarcane. Molecular Plant Pathology 3: pp.251-259.

Lai, H.T., Hou, J.-H., Su, C.-I., Chen, C.-L., 2009. Effects of chloramphenicol, florfenicol, and thiamphenicol on growth of algae Chlorella pyrenoidosa, Isochrysis galbana and Tetraselmis chui. Ecotoxicology and Environmental Safety 72: pp.329-334.

Lemos, Marco F. L., Soares, Amadeu M. V. M., Correia, António, C., Esteves, Ana C., 2010. "Proteins in ecotoxicology - How, why and why not?" PROTEOMICS 10 (4): pp.873-887.

LfU, 2009. Arzneimittelwirkstoffe und ausgewahite Metaboliten - Untersuchungen in bayerischen Gewassern 2004-2008. Bayerisches Landesamt fur Umwelt, Umwelt Spezial. http://www.lfu.bayern.de/wasser/gewaesserqualitaet_fluesse/karten_berichte_veroeffentlichu ngen/index.htm.

Li, M., Hu, C., Zhu, Q., Chen, L., Kong, A., Liu, Z., 2006. Copper and zinc induction of lipid peroxidation and effects on antioxidant enzyme activities in the microalga Pavlova viridis (Prymnesiophyceae). Chemosphere 62: pp.565-572.

Lienert, J., Gudel, K., Escher, B.I., 2007. Screening method for ecotoxicological hazard assessment of 42 pharmaceuticals considering human metabolism and excretory routes. Environmental Science and Technology 41: pp.4471-4478

Liu, B., Liu, W., Nie, X., Guan, C., Yang, Y., Wang, Z., Liao, W., 2011. Growth response and toxic effects of three antibiotics on Selenastrum capricornutum evaluated by photosynthetic rate and chlorophyll biosynthesis. Journal of Environmental Sciences 23(9): pp.1558-1563. 
Liu, Y., Guan, Y.T., Gao, B.Y., Yue, Q.Y., 2012. Antioxidant responses and degradation of two antibiotic contaminants in Microcystis aeruginosa. Ecotoxicology and Environmental Safety 86: pp.23-30.

Magdaleno, A., Saenz, M.E., Juarez, A.B., Moretton, J., 2015. Effects of six antibiotics and their binary mixtures on growth of Pseudokirchneriella subcapitata. Ecotoxicology and Environmental Safety 113: pp.72-78.

McCord, J.M., Fridovich, I., 1969. Superoxide dismutase. An enzymic function for erythrocuprein (hemocuprein). Journal of Biological Chemistry 244(22): pp.6049-6055.

McFadden, G.I., Roos, D.S., 1999. Apicomplexan plastids as drug targets. Trends in Microbiology 7: pp.328-333.

Nie, X.P., Lu, J.Y., Li, X., Yang, Y.F., 2007. Toxic effects of norfloxacin on the growth and activities of antioxidase of Chlorella pyrenoidosa. Asian Journal of Ecotoxicology 2(3): pp.327-332.

Nie, X.P., Liu, B.Y., Yu, H.J., Liu, W.Q., Yang, Y.F., 2013. Toxic effects of erythromycin, ciprofloxacin and sulfamethoxazole exposure to the antioxidant system in Pseudokirchneriella subcapitata. Environmental Pollution 172: pp.23-32.

OECD, 2000. Series on Testing and Assessment, No. 23: Guidance Document on Aquatic Toxicity Testing of Difficult Substances and Mixtures. ENV/JM/MONO(2000)6, OECD Paris.

OECD, 2006. Test No. 201: Freshwater alga and cyanobacteria, growth inhibition test. OECD Guidelines for the Testing of Chemicals. Paris.

Ohkawa, H., 1979. Assay for lipid peroxides in animal tissues by thiobarbituric acid reaction. Analytical Biochemistry 95: pp.351-358.

Orias, F., Perrodin, Y., 2013. Characterization of the ecotoxicity of hospital effluents. A review, Science of the Total Environment 454-455: pp.250-276.

Ortiz de Garcia, S., Pinto, G.P., Garcia-Encina, P.A., Irusta Mata, R.I., 2013. Ranking of concern, based on environmental indexes, for pharmaceutical and personal care products: an application to the Spanish case. Journal of Environmental Management 129: pp.384-397. 
Paes, C.R.P.S., Faria, G.R., Tinoco, N.A.B., Castro, D.J.F.A., Barbarino, E., Lourenco, S.O., 2016. Growth, nutrient uptake and chemical composition of Chlorella sp. and Nannochloropsis oculata under nitrogen starvation. Latin American Journal of Aquatic Research 44(2): pp.275-292.

Qian, H., Pan, X., Shi, S., Yu, S., Jiang, H., Lin, Z., Fu, Z. 2011. Effect of nonylphenol on response of physiology and photosynthesis-related gene transcription of Chlorella vulgaris. Environmental Monitoring and Assessment 182: pp.61-69.

Sies, H., 1997. Oxidative stress: oxidants and antioxidants. Experimental Physiology 82: pp.291-295.

Soto, P., Gaete, H., Hidalgo, M.E., 2011. Assessment of catalase activity, lipid peroxidation, chlorophyll-a, and growth rate in the freshwater green algae Pseudokirchneriella subcapitata exposed to copper and zinc. Latin American Journal of Aquatic Research 39(2): pp.280-285.

Sun, M., Lin, H., Guo, W., Zhao, F., Li, J., 2017. Bioaccumulation and biodegradation of sulfamethazine in Chlorella pyrenoidosa. Journal of Ocean University of China 16(6): pp.1167-1174.

Suter, G.W., 1996. Abuse of hypothesis testing statistics in ecological risk assessment. Human and Ecological Risk Assessment 2: pp.331-347.

Torres, M.A., Barros, M.P., Campos, S.C.G., Pinto, E., Rajamani, S., Sayre, R.T., Colepicolo, P., 2008. Biochemical biomarkers in algae and marine pollution: A review, Ecotoxicology and Environmental Safety 71: pp.1-15.

UBA, 2010. Zusammenstellung des Umweltbundesamtes nach Angaben der Landerarbeitsgemeinschaft Wasser (LAWA). Umweltbundesamt, Berlin.

USEPA (United States Environmental Protection Agency), 2002. Short-term methods for estimating the chronic toxicity of effluents and receiving waters to fresh water organisms (EPA-821-R-02-013), 4th ed., Washington DC, USA.

Van Camp, W., Van Montagu, M., Inze, D., 1994. Superoxide dismutases. In: Foyer C.H., Mullineaux P.M. (Eds.), Causes of photooxidative stress and amelioration of defence systems in plants. CRC Press, Boca Raton, pp.318-341. 
Van der Grinten, E., Pikkemaat, M.G., Brandhof van den, E.J., Stroomberg, G.J., Kraak, H.S.M., 2010. Comparing the sensitivity of algal, cyanobacterial, and bacterial bioassays to different groups of antibiotics. Chemosphere 80: pp.1-6.

Verslycke, T., Ghekiere, A., Janssen, C.R., 2004a. Seasonal and spatial patterns in cellular energy allocation in the estuarine mysid Neomysis integer (Crustacea: Mysidacea) of the Scheldt estuary (The Netherlands). Journal of Experimental Marine Biology and Ecology 306: pp.245-267.

Verslycke, T., Roast, S.D., Widdows, J., Jones, M.B., Janssen, C.R., 2004b. Cellular energy allocation and scope for growth in the estuarine mysid Neomysis integer (Crustacea: Mysidacea) following chlorpyrifos exposure: a method comparison. Journal of Experimental Marine Biology and Ecology 306: pp.1-16.

Villain, J., Minguez, L., Halm-Lemeille, M-P., Durrieu, G., Bureau, R., 2016. Acute toxicities of pharmaceuticals toward green algae, mode of action, biopharmaceutical drug disposition classification system and quantile regression models. Ecotoxicology and Environmental Safety 124: pp.337-343.

Yang, L-H., Ying, G-G., Su, H-C., Stauber, J.L., Adams, M.S., Binet, M.T., 2008. Growth inhibiting effects of twelve antibacterial agents and their mixtures on the freshwater microalga Pseudokirchneriella subcapitata. Environmental Toxicology and Chemistry 27(5): pp.1201-1208.

\section{Supplementary material}

Table S1. Results of the analytical determination of studied antibiotics.

\begin{tabular}{llllllll}
\hline Nominal conc $\mu \mathrm{M}$ & $0 \mathrm{~h}$ & $\% \mathrm{~N}$ & $48 \mathrm{~h}$ & $\% \mathrm{~N}$ & $120 \mathrm{~h}$ & $\% \mathrm{~N}$ & Mean exp conc \\
\hline Erythromycin & & & & & & & \\
& & & & & & \\
$8.00 \times 10^{-3}$ & $6.13 \pm 0.09$ & 98.1 & $5.96 \pm 0.08$ & 95.3 & $5.40 \pm 0.27$ & 86.5 & nd \\
$1.19 \times 10^{-2}$ & $8.52 \pm 0.19$ & 97.4 & $8.33 \pm 0.23$ & 95.2 & $7.56 \pm 0.23$ & 86.4 & nd
\end{tabular}




$\begin{array}{llllllll}1.70 \times 10^{-2} & 12.18 \pm 0.18 & 97.4 & 11.95 \pm 0.27 & 95.6 & 10.84 \pm 0.19 & 86.7 & \text { nd } \\ 4.08 \times 10^{-2} & 28.81 \pm 0.98 & 96.0 & 27.95 \pm 0.66 & 93.1 & 25.24 \pm 1.19 & 84.1 & \text { nd }\end{array}$

\begin{tabular}{|c|c|c|c|c|c|c|c|}
\hline \multicolumn{8}{|c|}{ Clarithromycin } \\
\hline $1.3 \times 10^{-3}$ & $1.01 \pm 0.03$ & 101.2 & $0.14 \pm 0.01$ & 14.6 & $0.09 \pm 0.00$ & 9.3 & $2.8 \times 10^{-4}$ \\
\hline $3.3 \times 10^{-3}$ & $2.64 \pm 0.40$ & 105.7 & $0.24 \pm 0.02$ & 9.5 & $0.10 \pm 0.02$ & 4.3 & $4.6 \times 10^{-4}$ \\
\hline $4.6 \times 10^{-3}$ & $3.39 \pm 0.18$ & 97.0 & $0.33 \pm 0.05$ & 9.6 & $0.11 \pm 0.02$ & 3.1 & $6.0 \times 10^{-4}$ \\
\hline $7.3 \times 10^{-3}$ & $4.89 \pm 0.10$ & 89.0 & $0.39 \pm 0.07$ & 7.2 & $0.14 \pm 0.02$ & 2.6 & $7.6 \times 10^{-4}$ \\
\hline \multicolumn{8}{|c|}{ Ciprofloxacin } \\
\hline 3.02 & $1291 \pm 0.27$ & 129.1 & $1340 \pm 0.11$ & 134.0 & $989 \pm 0.10$ & 98.9 & 3.7 \\
\hline 6.04 & $1730 \pm 0.08$ & 86.5 & $2320 \pm 0.08$ & 116.2 & $1470 \pm 0.18$ & 73.5 & 5.8 \\
\hline 12.08 & $4300 \pm 0.73$ & 107.6 & $3970 \pm 1.15$ & 99.4 & $3140 \pm 0.77$ & 78.5 & 11.5 \\
\hline 24.17 & $8100 \pm 2.00$ & 101.2 & $7490 \pm 0.21$ & 93.6 & $3560 \pm 0.64$ & 44.5 & 19.1 \\
\hline \multicolumn{8}{|c|}{ Sulfamethoxazole } \\
\hline 0.24 & $67.0 \pm 0.01$ & 108.0 & $56.0 \pm 0.01$ & 89.6 & $69.0 \pm 0.01$ & 111.4 & nd \\
\hline 1.97 & $480 \pm 0.18$ & 96.4 & $513 \pm 0.00$ & 102.6 & $210 \pm 0.10$ & 43.1 & 1.58 \\
\hline 3.95 & $1170 \pm 0.43$ & 117.7 & $1024 \pm 0.44$ & 102.4 & $263 \pm 0.12$ & 26.3 & 2.96 \\
\hline 13.83 & $3260 \pm 1.01$ & 93.3 & $1900 \pm 0.65$ & 54.4 & $1610 \pm 0.79$ & 46.1 & 8.30 \\
\hline
\end{tabular}

* Mean exposure concentration $\mu \mathrm{M}$ (geometric mean of 0, 48, and $120 \mathrm{~h}$ ); Mean $\pm \mathrm{SD}$ (3 to 7 replicates). nd: not determined (nominal concentrations used because measured concentrations within limits recommended by OECD 2006) 